\title{
MEMORIA INSCRITA. ARTE RUPESTRE DE CONTACTO, INTEGRACIÓN Y DOMINACIÓN EN EL CENTRO-SUR DE CHILE
}

\section{ENGRAVED MEMORY. THE CONTACT PERIOD ROCK ART, INTEGRATION AND DOMINATION IN SOUTH-CENTRAL CHILE}

\author{
José Francisco Blanco * Magdalena de \\ LA MAZA* * \& MARÍA ÁNGELA PEÑALOZA * * *
}

Este trabajo presenta una discusión acerca de la memoria indígena y sus expresiones visuales y materiales para Chile centro-sur, del Período Intermedio Tardío en adelante (siglos $\mathrm{XI}$-XVIII). Se entrega información inédita de dos sitios de arte rupestre en Chile central: Cerro Los Ratones y Los Luchos, recientemente descubierto. Se relacionan ambos registros y se discuten respecto de otros conocidos. Luego se examina el arte rupestre más sureño por medio de sus correlatos textuales y materiales, proponiendo algunas hipótesis para su interpretación.

Palabras clave: arte rupestre, Chile centro-sur, períodos tardíos

This work discusses the indigenous memory and its visual and material expression in South-Central Chile, from the Late Intermediate period onward ( $11^{\text {th }}-18 \mathrm{th}$ centuries). The authors provide new information for two rock art sites in Central Chile: Cerro Los Ratones and Los Luchos, recently discovered, comparing and analyzing them in light of other known examples. The article then examines the textual and material correlations with rock art further south, proposing bypotheses for interpretation.

Key words: rock art, central and south Chile, late periods
Uya ngillañmawün mew inche, puen, Mari füda epuyawün. ${ }^{1}$

La memoria es uno de los atributos que mejor caracteriza a la mente humana, indisociable del aprendizaje y principal a la constitución del ser social y la cultura. Permite a individuos y a grupos definirse a sí mismos, o bien, ser definidos por otros. Configura en gran medida lo que el mundo es, siendo fundamental a cualquier cosmovisión (cf. Rowlands 1993). En suma, hace posible la existencia de la identidad (para una retrospectiva arqueológica, ver Hides 1996) y, sea cual sea el tipo de memoria que se esté invocando, según su procedencia o propósito,

[...] apelamos a nuestra memoria para responder a preguntas que los demás nos hacen, o que nosotros imaginamos que podrían preguntarnos, y para poder responder, nos vemos a nosotros mismos como formando parte del mismo grupo o grupos al que ellos pertenecen. Muy frecuentemente, si recuerdo algo es porque otros me han incitado a recordarlo, a causa de que su memoria viene en ayuda de la mía y la mía encuentra soporte en la de ellos (Connerton 1989: 36). ${ }^{2}$

En lo práctico, la memoria es codificable en elementos externos, fijándose en objetos por técnicas y reglas de inscripción e interpretación que son propias a cada

* José Francisco Blanco, Programa de Doctorado en Arqueología, Universidad Nacional del Centro de la Provincia de Buenos Aires (UNICEN), Olavarría, Argentina. Carampangue 153, piso 3, Valparaíso, Chile, email: jfblanco@gmail.com

* Magdalena De La Maza, Facultad de Ciencias Sociales, Universidad de Chile, Av. Capitán Ignacio Carrera Pinto N ${ }^{\circ} 1045$, Ñuñoa, Santiago de Chile, email: magdalenadelamaza@gmail.com

*** María Ángela Peñaloza, Facultad de Ciencias Sociales, Universidad de Chile, Av. Capitán Ignacio Carrera Pinto Nº 1045 , Ñuñoa, Santiago de Chile, email: angecabj@gmail.com 
sociedad. La antropología, la etnohistoria y la arqueología han mostrado cómo distintos pueblos formalizaron sus memorias con arreglo a su propia experiencia de lo evocado y empleando distintas herramientas mnemónicas (Hides 1996; Martínez, J. L. 2009, 2010).

Un ejemplo importante de esto se advierte en el encuentro entre las culturas andinas y el estado eclesiástico occidental representado por la Corona española. Durante las últimas décadas, la etnohistoria ha señalado el sesgo en los textos escritos por el aparato estatal, religioso y jurídico español desde la conquista, que produjo una "textualización" de la memoria indígena andina, hasta entonces principalmente oral (Salomon 1994). Del mismo modo, se ha descrito cómo los españoles transformaron una memoria ritual en una histórica (Pease 1997), con un propósito colonizador de las memorias indígenas (Mignolo 1992).

Tomando en cuenta esto, puede decirse que muchos de los documentos históricos reflejarían, más que la realidad, la forma en que el español quiso referirse a los andinos, por cuestiones de orden hegemónico. En una perspectiva escalar, el volumen de los documentos españoles -y en general occidentales- que se refieren a los indígenas supera quizá las centenas de miles de páginas que interpretan sesgadamente -unas más y otras menos- la historia previa a la conquista o los sucesos en que indígenas y españoles coparticiparon.

Por contraparte, hay solo un documento en que el indígena se refiere a su mundo en su propia lengua (Manuscrito de Huarochirí, Taylor 2008) y algunos pocos autores indígenas en español que, a pesar de su indudable valor, probablemente estaban también mediados por un afán de pertenencia al sistema impuesto por el conquistador (p. e., Guamán Poma, Pachacuti). Por esto, no han estado exentos de crítica en cuanto a sus propósitos y mentalidad autoral (Duviols 1997; Itier 1997), siendo conocidas sus condiciones de formación escritural (Martínez, P. 2011).

Además, las imágenes del arte indígena fueron condenadas expresamente por el Estado español -por medio de ordenanzas virreinales- a su destrucción sistemática y alevosa (cf. Martínez, J. L. 2009). Mientras esto ocurría, aparentemente, la pintura europea y sus referentes eran estimulados, como puede entenderse del encargo de Francisco de Toledo a los pintores cusqueños, reseñado por Dorta (1975). Aun en estas pinturas, puede decirse que "[...] se ha puesto en evidencia las tensiones ideológicas que las atraviesan y su impronta eminentemente colonial" (Estenssoro 2005: 93).

A pesar de la enorme desigualdad de las "fuentes", textos e imágenes, la investigación ha demostrado una cuestión importante: que aunque las sociedades andinas no desarrollaran medios escritos de registro y representación del pasado, enfatizaron en otras formas de la memoria para cautelar y transmitir sus tradiciones, costumbres y, en fin, su conocimiento. En este sentido, recientemente, autores como C. Allen (2002), R. Hostnig (2004) y J. L. Martínez (2009, 2010) han mostrado convincentemente cómo subsisten estas memorias andinas indígenas en soportes diferentes de la escritura. Ya sean quipus, keros, varas, tablas, textiles o arte rupestre, en cada uno de estos sistemas es posible descubrir ejemplos de memoria verificables contra las fuentes escritas del proceso histórico y que perviven en el concierto del conflicto con un Estado dominador y violento.

En este trabajo nos referiremos, desde la arqueología, al arte rupestre como vehículo de tales memorias, empleando ejemplos del área meridional andina entre los ríos Huasco y Maule (fig. 1) y los siglos XI al XIX, con una breve introducción a los momentos previos. Presentaremos, para ilustrar el proceso, el caso de una localidad cordillerana de Chile central en la que creemos posible identificar a distintas sociedades inscribiendo memoria en la piedra diacrónicamente. Más adelante, nos referiremos a la correspondencia entre registros visuales, artefactuales y documentos (a partir del siglo XVI) en la sección más sureña del área propuesta, que refieren a la permanencia de la memoria indígena, tal como se ha señalado para otras partes del mundo andino.

\section{COMPLEJOS CULTURALES E ICONOGRAFÍA PREHISTÓRICA DE CHILE CENTRO-SUR}

A manera de antecedente, intentaremos aquí un esbozo general de la decoración y la iconografía de sociedades prehistóricas de Chile centro-sur, por bloque temporal y áreas, que permitirá trazar algunas continuidades y diferencias para su discusión posterior. Incluiremos algún comentario referido a las sociedades de la región norte semiárida (o Norte Chico), sin las cuales no puede entenderse la problemática de Chile central. Debe indicarse aquí que se conocen escasos referentes que pudieran considerarse como motivos decorativos de poblaciones arcaicas, ${ }^{3}$ que no trataremos aquí, y que enfatizaremos solo en algunos diseños que podremos reconocer después en el arte rupestre.

Se han descrito para Chile central dos complejos culturales alfareros tempranos, Bato (ca. 300 AC-800 DC) y Llolleo (200-1100 DC), con distribución general entre los ríos Aconcagua y Cachapoal. El primero, Bato, muestra decoración cerámica por campos, sin referentes identificables, con elementos geométricos lineales, 


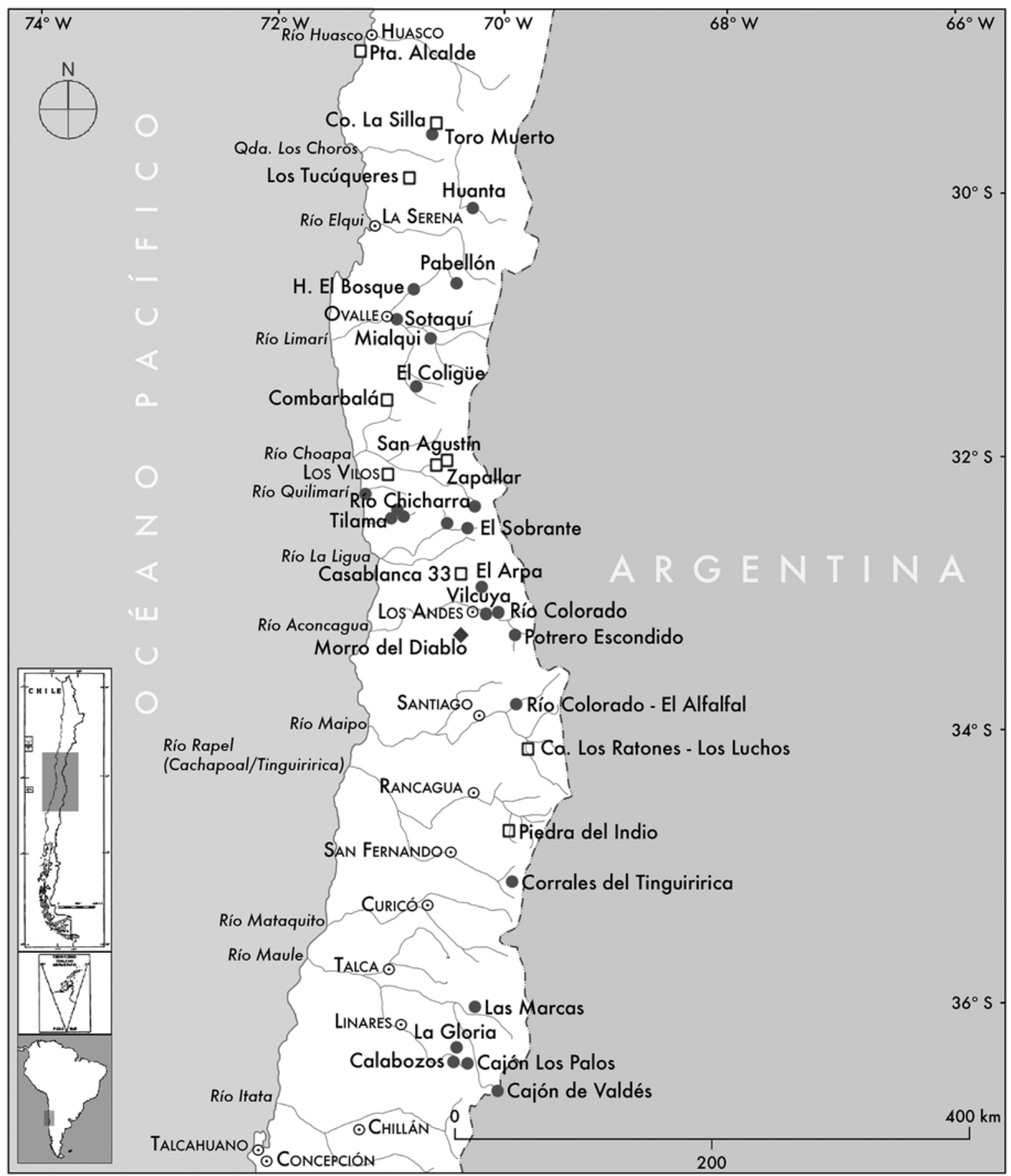

Figura 1. Lugares que se mencionan en el texto y sus cuencas hidrográficas. Chile entre $28^{\circ}$ y $37^{\circ}$ LS: Desierto semiárido, Chile central, y sur de Chile.

Figure 1. Places mentioned in the text, with the corresponding water basins. Semi-arid desert $\left(28^{\circ}-37^{\circ}\right.$ S latitude), Central and Southern Chile.

generalmente dispuestos en diagonal (Falabella \& Stehberg 1989). De un sitio costero en la desembocadura del Aconcagua (ENAP-3, Berdichewsky 1964) puede señalarse un motivo decorativo para esta tradición, en una orejera (fig. 2).
Por su parte, Llolleo (Sanhueza \& Falabella 2009), algo más tardío y con presencia hasta ca. 1100 DC, ofrece algunas decoraciones modeladas en la cerámica, destacando la representación antropomórfica de rostro con ojos tipo "grano de café" y cejas continuas (fig. 3). 


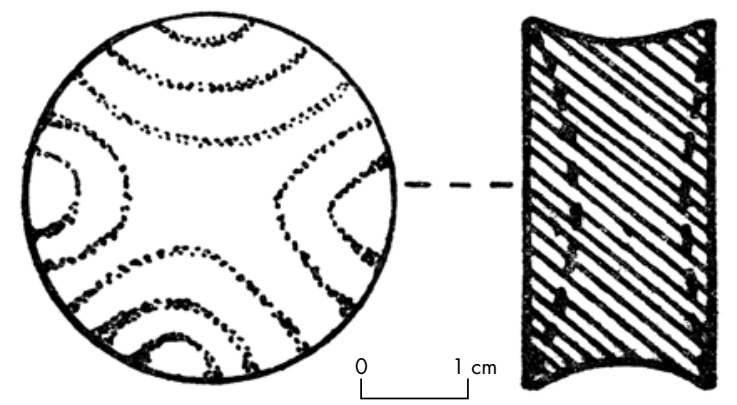

Figura 2. Motivo decorativo Bato, orejera (Berdichewsky 1964: 76). Figure 2. Bato decorative motif, earornament (Berdichewsky 1964: 76).

Conviene notar que, a grandes rasgos, ambos complejos guardan similitudes con otros más distantes. Falabella \& Stehberg (1989: 311) sostienen que "pese a la orientación sureña, es innegable la existencia de contactos Llolleo con el área del Choapa". Por contraparte, refiriéndose al período en esta última área (desierto semiárido), Ampuero (1989: 287) indica que "Durante el periodo agroalfarero medio (800-1200 DC) las sociedades precolombinas de nuestra región entraron en conflicto y relaciones con las de más al sur...". Igualmente, existirían relaciones estilísticas de las poblaciones de Chile central con Pitrén, más al sur y algo más tardíamente (Correa 2009). Todo ello nos advierte de una base estilística común desde muy temprano en el tiempo.

Un desarrollo posterior, desde ca. 1000 DC, es la Cultura Aconcagua (Durán \& Massone 1979), con continuidad hasta épocas inkaicas, con su área nuclear en el interfluvio Mapocho-Maipo (Sánchez et al. 2004), pero con distribución importante en los cursos medio y bajo del río Aconcagua y evidencias hasta La Ligua (Ávalos \& Saunier 2011). Difiere notablemente de los anteriores por funebria, patrón de asentamiento y formas y tecnología cerámica (Durán \& Planella 1989). En lo decorativo, sus patrones cerámicos marcan un especial interés por las construcciones visuales circulares y sus particiones, con simetrías reflejas, bilaterales y axiales. Su motivo más notable es el "trinacrio" (fig. 4, abajo derecha).

En asociación a Aconcagua, debe mencionarse a la cultura Diaguita chilena, en los valles del semiárido al norte de nuestra área de estudio. Al respecto, Durán \& Planella (1989: 325) indican: "Los restos arqueológicos en la Zona Central apuntan a señalar que al menos entre la población Diaguita y la Aconcagua, parece haber gravitado más un esquema de integración que de contactos esporádicos", habiéndose propuesto también una relación "interdigitada” (sensu Martínez, J. L. 1998) de dichas poblaciones, por Sánchez y colaboradores (2004).

El arte diaguita es sumamente variado y complejo, y no es pertinente referirnos in extenso a las características de este registro, propio de mucho más al norte, los valles del Limarí y el Elqui, de donde procede la mayor parte del material de sus fases II y III, esta última, de influencia inkaica (Cantarutti 2002; González 2013). Presentamos ejemplos muy generales en la figura 5 , en atención a la antedicha integración de estas poblaciones. Nótese, en interés de las disquisiciones siguientes, la morfología de hachas y cuchillos en la fila inferior, de la última fase diaguita (ver fig. 5).

Por último, el complejo El Vergel caracteriza el espacio adyacente más al sur del área de estudio propuesta, la Araucanía, del 1000 al 1550 DC, y presenta algunos patrones decorativos similares a Aconcagua y Diaguita, pero también, con decorados de posible vinculación a los inkaicos (fig. 6). Estudios recientes son los de Bahamondes (2009 y 2010), con resultados que apoyan esta conexión en el marco de un proceso de andinización.

\section{LOS ÍCONOS DEL INKA Y SU INTERPRETACIÓN PROVINCIAL}

Una de las discusiones más interesantes en el área andina acerca de memorias escritas versus otros soportes es la de la frontera meridional del Inka, su momento de arribo y ámbito de expansión. Desde la etnohistoria se plantea como fecha límite más o menos segura 1470 DC (León 1983), durante Topa Inka Yupanqui y consolidado por Huayna Cápac más tarde, mientras que las fechas arqueológicas apuntan a un momento más temprano entre 1360 y 1400 DC (Stehberg 1995; Sánchez 2004). Del mismo modo, la tradicional frontera inkaica en el valle de Santiago ha sido avanzada hasta el río Cachapoal por sitios como los del cerro Tren-Tren en Doñihue (Stehberg \& Rodríguez 1989), cerro Grande de La Compañía (Planella \& Stehberg 1994) y La Muralla (p. e., Sepúlveda et al. 2014).

En términos muy generales, el tratamiento más acertado del tema nos parece el de Dillehay \& Gordon (1995), quienes proponen una frontera geopolítica y otra geoeconómica en lugares distintos. A este panorama habría que agregar, como ya indicáramos, la posibilidad de "interdigitación" de poblaciones, propuesta como hipótesis por J. L. Martínez (1998) para el siglo XVII en Atacama, y planteada para Chile central en tiempos tardíos por Sánchez (2004) y Sánchez \& Troncoso (2008). 

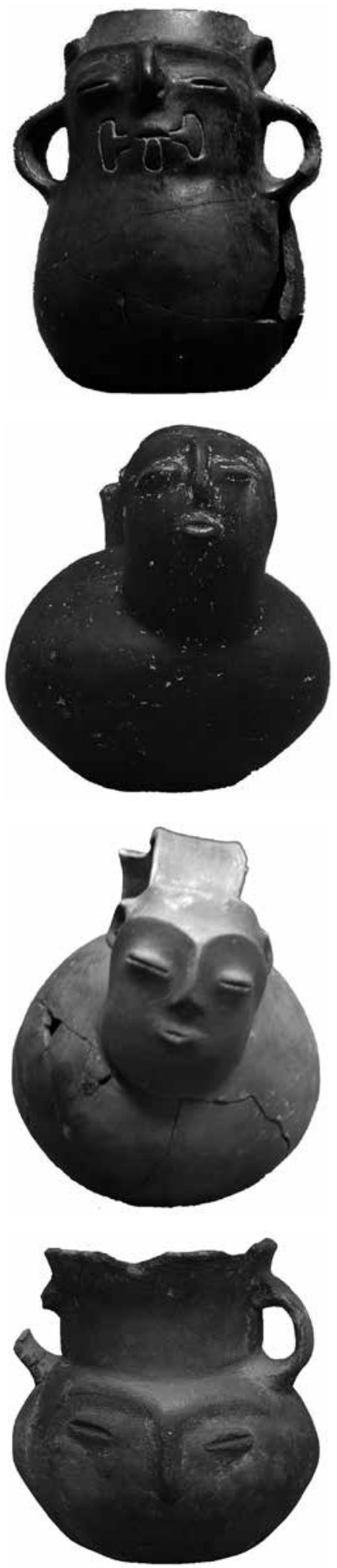

Figura 3. Ejemplares de motivo antropomorfo Llolleo, en cerámica (Correa 2009: 50, 51, 80, 82).

Figure 3. Examples of Llolleo anthropomorphic motif, ceramic vessels (Correa 2009: 50, 51, 80, 82).

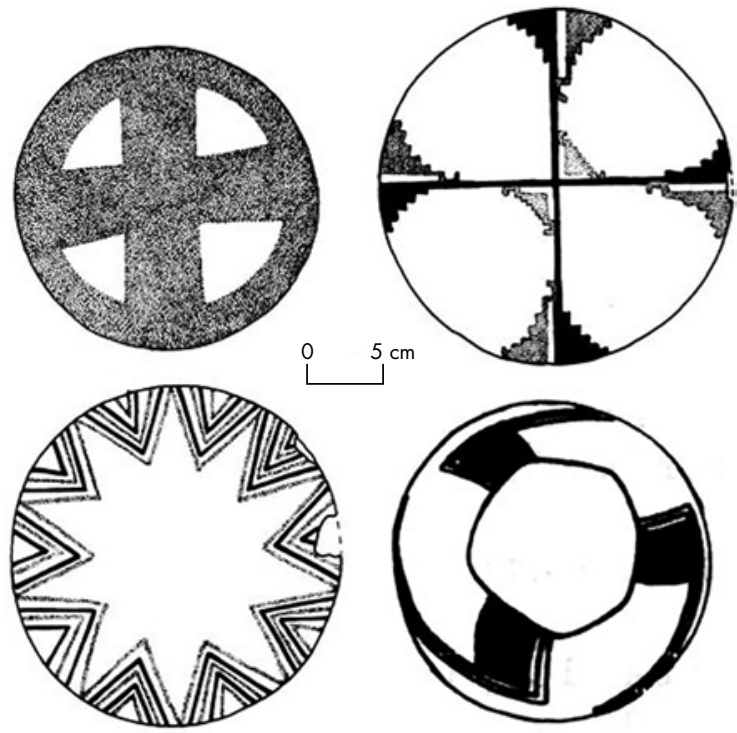

Figura 4. Decoración Aconcagua. Durán \& Planella (1989: 321-322, 326) y Durán (1979: 263).

Figure 4. Aconcagua decoration. Durán É Planella (1989: 321-322, 326) and Durán (1979: 263).

Como fuera, la presencia inkaica generó importantes cambios en el conjunto ergológico e iconografía de las poblaciones locales. Siguiendo a Bray (2004) y González (2004), algunos de los motivos del Inka que cabe destacar son: los diseños fitomorfos, "helechos", frecuentes en los aribaloides Diaguita-Inka e Inka local y en otros recipientes para líquidos; las "clepsidras", asociadas a las mismas formas; los campos ajedrezados similares a los unkus, en aríbalos, platos y escudillas; la presencia de "tocapus" y rectángulos concéntricos en un número más limitado de casos, y la "clave inka", una doble diagonal cruzada, a veces con círculos en sus extremos (ver p. e., Montt \& Pimentel 2009). En la figura 7 se muestran a la izquierda arriba tres aríbalos cusqueños (Bray 2004); al medio, cuatro platos Aconcagua con rombos concéntricos, y, abajo, un aribaloide y una escudilla con antropomorfos con unku Diaguita-Inka. Por cierto que el comportamiento de los diseños varía de región a región (Bray 2004).

\section{EL ARTE RUPESTRE DE CHILE CENTRO- SUR EN TIEMPOS PREHISPÁNICOS}

Fueron los trabajos de Hans Niemeyer los primeros que entregaron una sistematización analítica del arte rupestre de la zona centro-sur de Chile, entre el río Aconcagua y la cordillera de Linares. Este autor compiló una gran 


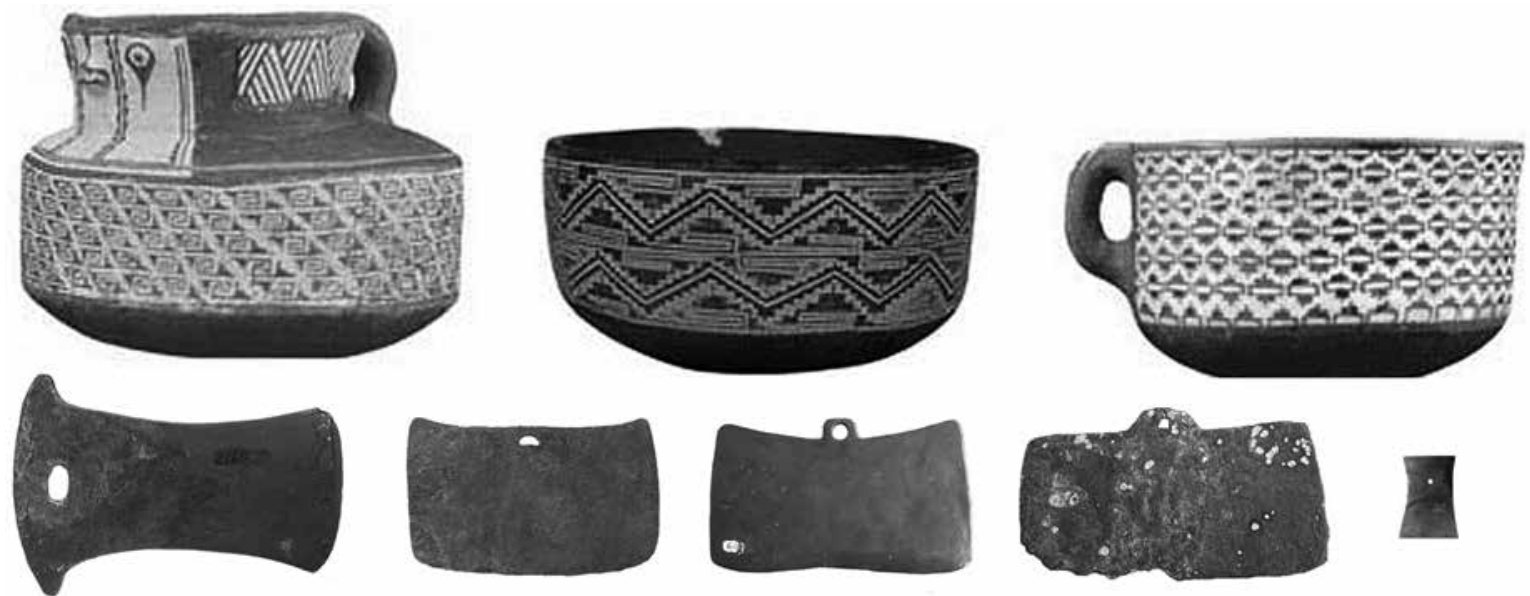

Figura 5. Decoración y artefactos Diaguita. Arriba, en cerámica, tres piezas Diaguita II (Ampuero 1978: 43, 34, 42). Abajo, en metal, hacha, cuchillos y "canipu" (Latorre 2009: 135, 140; Latorre \& López 2011: 325).

Figure 5. Diaguita decoration and artifacts. Top: three Diaguita II ceramic pieces (Ampuero 1978: 43, 34, 42). Bottom: metal axe, knives and "canipu" insignia (Latorre 2009: 135, 140; Latorre \& López 2011: 325).

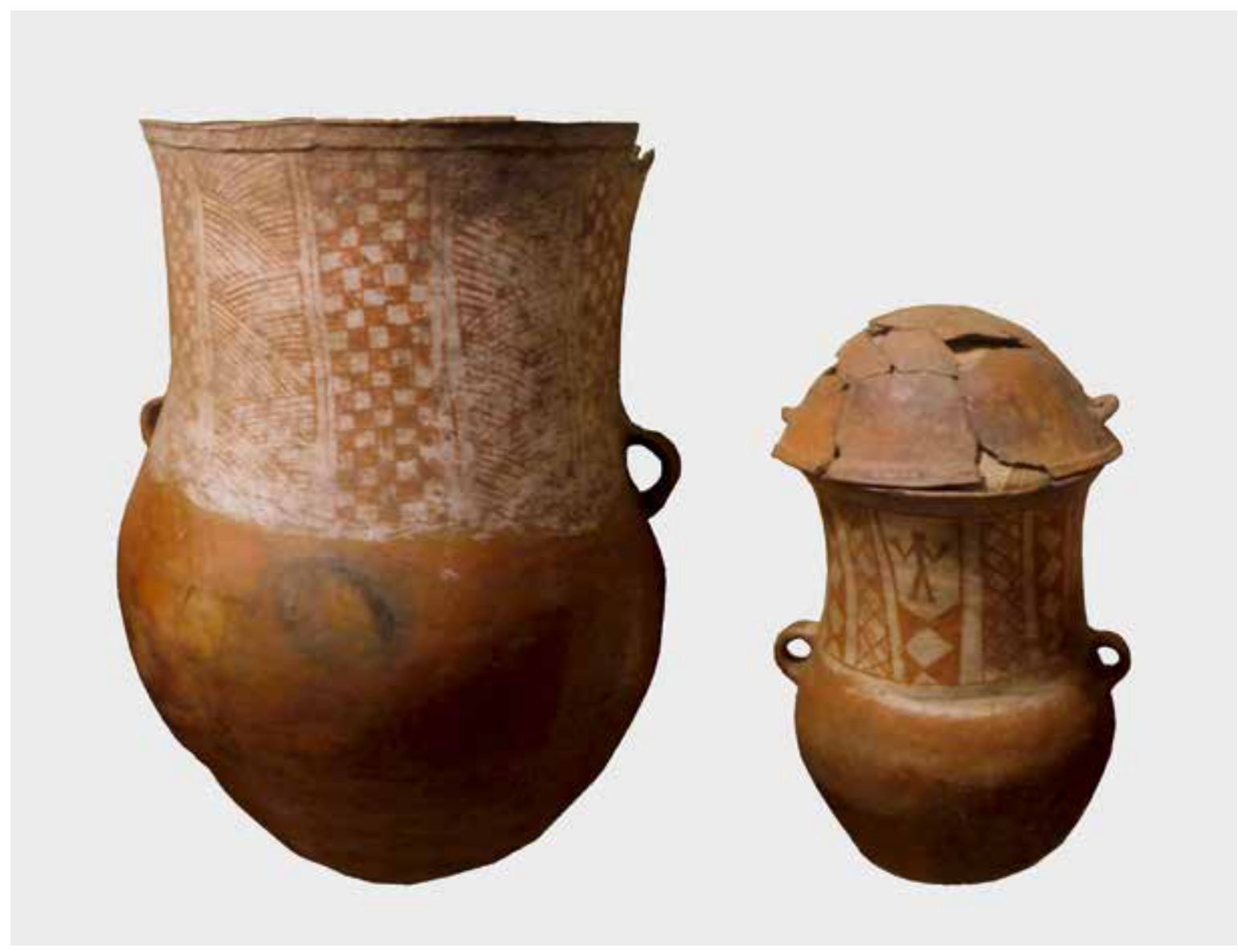

Figura 6. Piezas cerámicas Vergel (Bahamondes 2009: 136, Museo Dillman Bullock).

Figure 6. Vergel ceramic pieces (Bahamondes 2009: 136, Museo Dillman Bullock). 

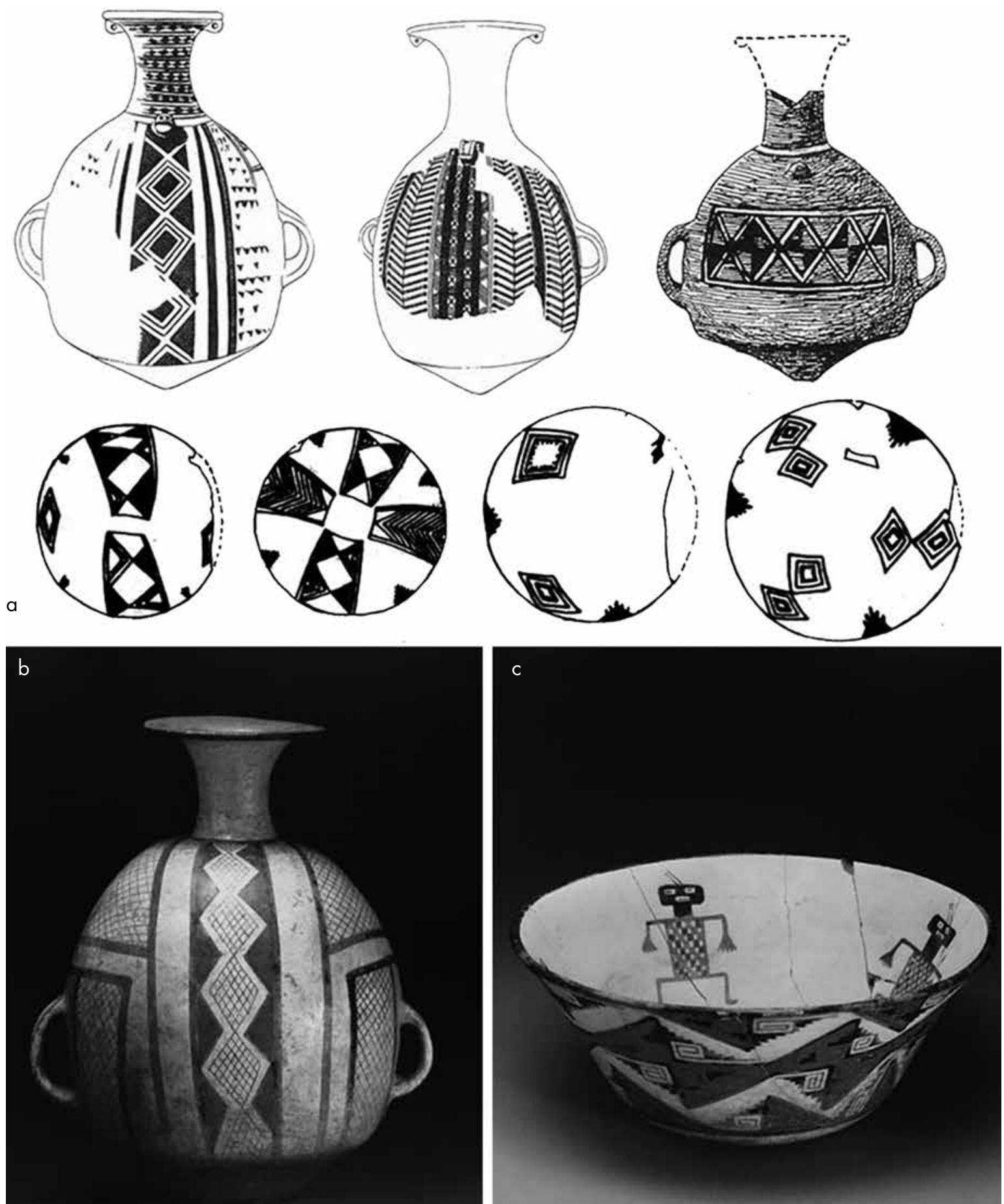

Figura 7. Ejemplos de iconografía en cerámica inkaica y sus interpretaciones "provinciales”: a) Bray (2004: 371); b) Durán (1979: 263); c) Museo Chileno de Arte Precolombino (1991: 71, 75).

Figure 7. Inka ceramic iconography and "provincial" interpretations: a) Bray (2004: 371); b) Durán (1979: 263) and c) Museo Chileno de Arte Precolombino (1991: 71, 75). 
cantidad de registros que le permitieron proponer dos estilos: el Guaiquivilo (Niemeyer \& Weisner 1972-1973), de filiación sureña, y, más tarde, el Aconcagua (Mostny \& Niemeyer 1983), correspondiente a la sección centro de nuestra área de estudio.

El Estilo Aconcagua ha sido discutido principalmente en referencia a los llamados "signos escudo" (fig. 8). La crítica más importante del tema ha sido realizada por Troncoso (cf. 2006a), proponiendo la contemporaneidad de estos con el Inka. En nuestros ejemplos, los de arriba muestran asociación a la doble diagonal cruzada ("clave inka"); pero los dos de abajo a la izquierda recuerdan a la orejera Bato (ver fig. 2) y a la decoración de los tambores ceremoniales mapuche -kultrunes- de tiempo etnográfico (ver Aldunate 2009: 145); en tanto que los dos restantes, por su parte, podrían evocar algunos toki-mano, emblemas de mando que consisten en un hacha de piedra con ranuras paralelas en un extremo (p. e., Valenzuela 1964), cuya única asociación directa conocida es a un entierro Aconcagua en La Ligua (Ávalos et al. 1999-2000).

La ambigüedad temporal del arte rupestre Aconcagua y la deconstrucción de sus referentes son encaradas por Troncoso (2001, 2004, 2005, 2006a y b) y Pavlovic y colaboradores (2003), proponiendo diferencias específicas entre los bloques pre y postinkaicos. El primero tendría preferencia por la figura circular lineal simple, la representación humana circular con ausencia de figura individual, los ordenamientos diagonales y la yuxtaposición en la composición. En tanto, la época inkaica destacaría por sus figuras cuadrangulares, lineales inscritas, su redefinición de la figura humana (individualizada) y la superposición y ordenaciones ortogonales.

Con relación a Aconcagua, es importante destacar algunos elementos del arte rupestre de Estilo Limarí (Mostny \& Niemeyer 1983), asociado tradicionalmente al Complejo El Molle, pero que contendría también elementos de momentos posteriores que conviene separar de este (Troncoso et al. 2008). Para el semiárido más sureño existe un ilustrativo estudio acerca de petroglifos del río Choapa, por Jackson y colaboradores (2002). Debe tenerse en mente que la discusión respecto de este estilo y sus asociaciones no se ha resuelto aún. ${ }^{4}$ Si bien sus máximos exponentes son las imponentes representaciones de rostros (cabezas-tiara o mascariformes, cf. Cabello 2005), nos detendremos en motivos más discretos que serán útiles para nuestra discusión, como los que presentamos en la figura 9, muy probablemente de filiación tardía.

También existe activa discusión referida a la expresión rupestre de la iconografía propiamente inkaica, para ello se han postulado ejemplos de toda el área andina. Para nuestra zona destacaremos los ejemplos provistos por Troncoso (2004: 174-175) en el Tártaro 4 y Quebrada Honda 4: cruz inscrita y clepsidra. Debe destacarse que en el cordón del Chacabuco se ha descrito un ajedrezado tipo "unku" en una pintura (Morro del Diablo, cf. Berenguer 2012 Ms).

Por otra parte, con distribución entre los ríos Aconcagua y Maule, el Estilo Guaiquivilo muestra gran variabilidad iconográfica, con "fitomorfos", improntas de pie y huellas animales, grecas, triángulos concatenados y otras muchas formas (fig. 10).

Respecto de su cronología, aun cuando existen superposiciones:

[...] estas no permiten establecer cronología relativa y más bien nos inclinamos a creer que la tradición de grabar en la cordillera del Melado no fue muy prolongada en el tiempo. En suma, la edad de los grabados puede remontarse a nuestro parecer, a los siglos XII al XVI (Niemeyer \& Weisner 1972-1973: 468).

Se ha relacionado este estilo con el sitio Colo Michicó en la cordillera del Viento del Neuquén y con varios otros en cuencas al norte, incluyendo el Aconcagua. Para el territorio argentino se ha sostenido que su edad iría solo del siglo XII al XIV (Fernández 1979 en Vega et al. 1996).

\section{EL ARTE RUPESTRE DEL PERÍODO HISTORICO}

Existen distintos lugares en los Andes donde se ha constatado la pervivencia del arte rupestre indígena durante tiempos coloniales y su indicador más importante han sido los motivos transportados por el artista indígena desde la iconografía religiosa, las vestimentas o los atributos anexos portados por el colonizador europeo (cf. Martínez 2009). Generalizaremos desde el planteamiento tipológico de Hostnig (2004), distinguiendo cinco grupos: motivos religiosos, cruces, iglesias y curas; jinetes y escenificación de acciones castrenses, caballos y personajes armados (p. e., Gallardo et al. 1990); objetos, y otros motivos. En particular, las cruces serán útiles para nuestra discusión (fig. 11).

Para el Norte Chico se conocen los sitios Toro Muerto (Martínez, J. L. 2009; Martínez \& Arenas 2009; Arenas 2011), Punta Alcalde y El Coligüe; Canelillo 11 y 26 y Zapallar 9 (Jackson et al. 2002: 79-80), mientras que para Chile central solo existe noticia de un sitio con arte indígena de referente europeo, que ha sido presentado por Troncoso (2005). Este es el sitio Casablanca 33, en Putaendo, donde un jinete constituye el ejemplo más sureño conocido de este tipo de motivo (ver fig. 1). 

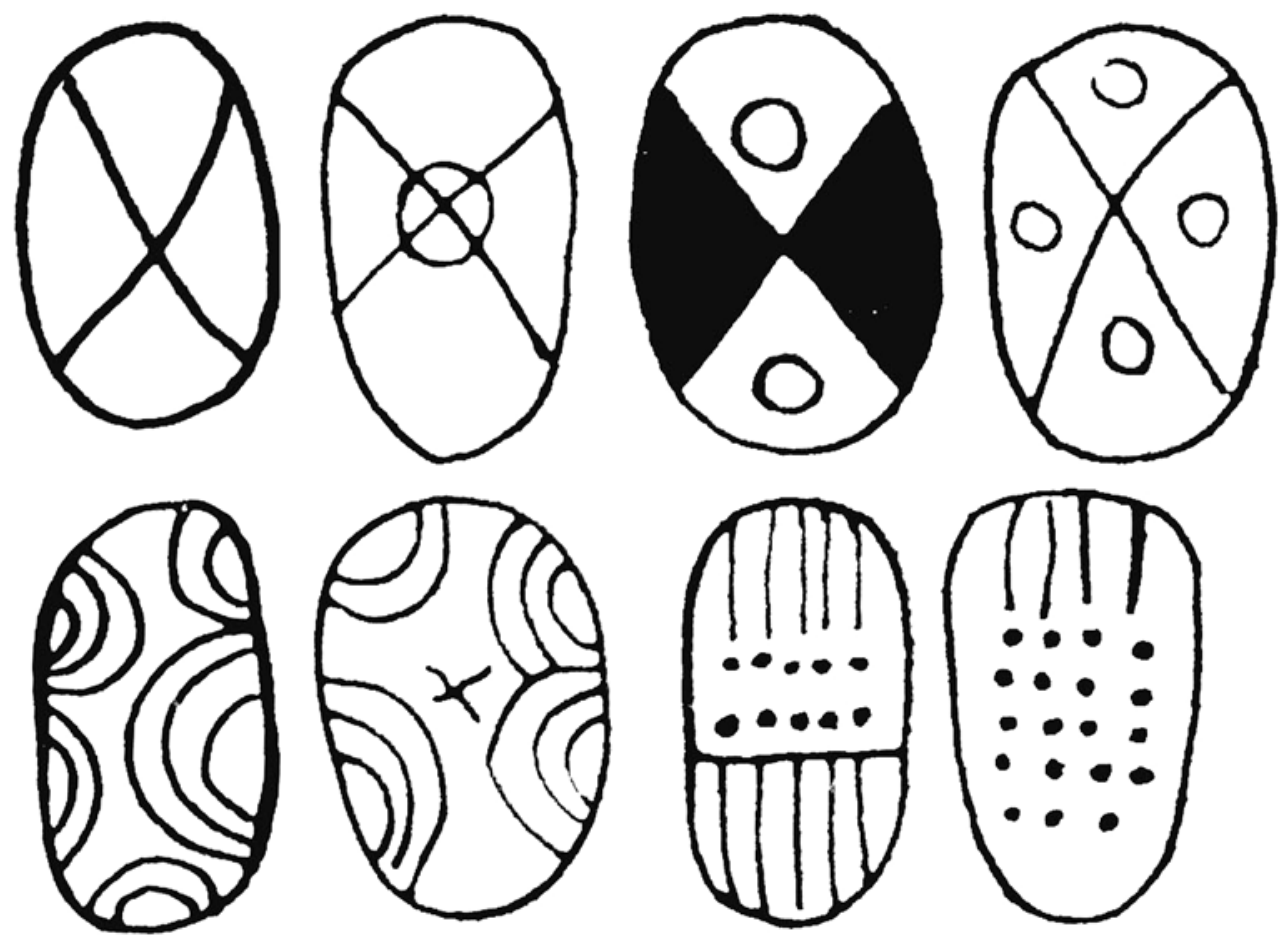

Figura 8. "Signos escudo" de Estilo Aconcagua (Mostny \& Niemeyer 1983: 70, 71, 74).

Figure 8. Aconcagua-style "shield signs" (Mostny \& Niemeyer 1983: 70, 71, 74).
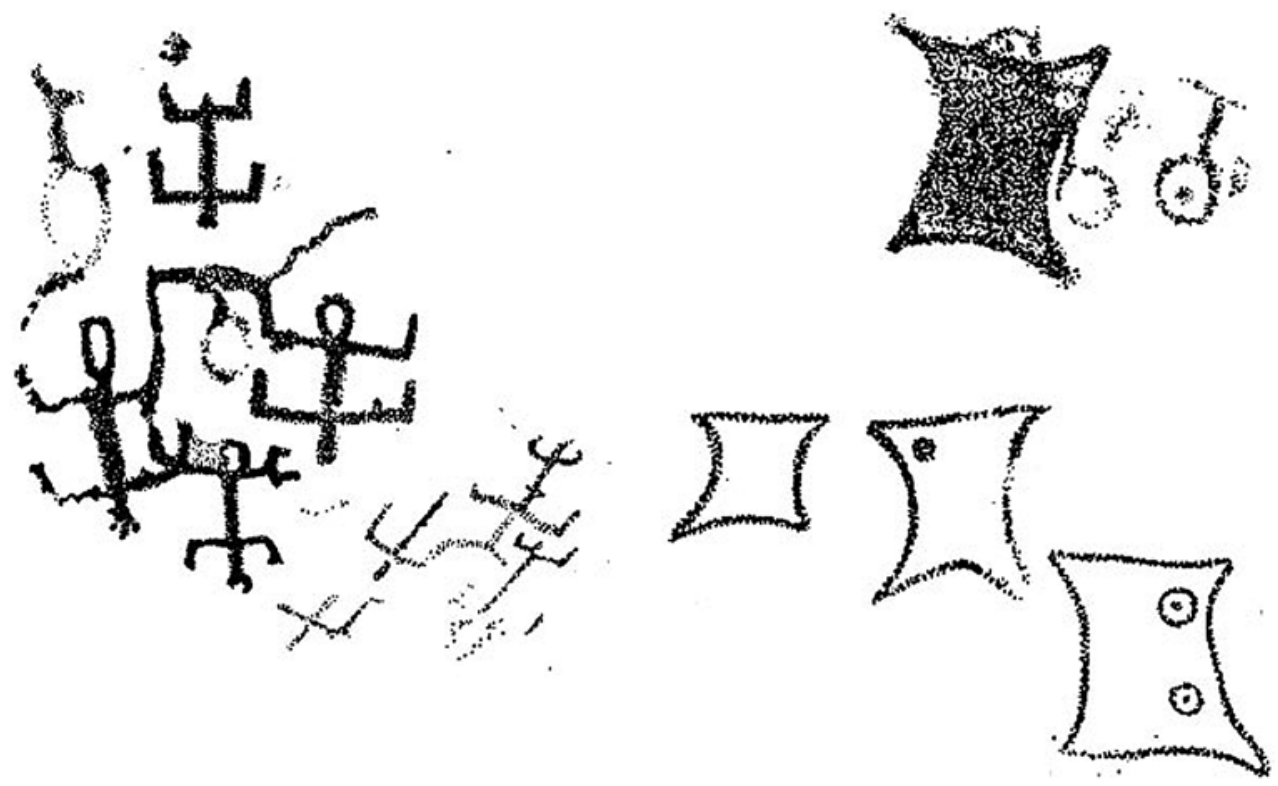

Figura 9. Motivos rupestres tardíos del norte semiárido. Carretón Bajo, Huana y Sotaquí (Mostny \& Niemeyer 1983: 60, 62). Figure 9. Late rock art motifs from the semi-arid North. Carretón Bajo, Huana and Sotaqui (Mostny E Niemeyer 1983: 60, 62). 


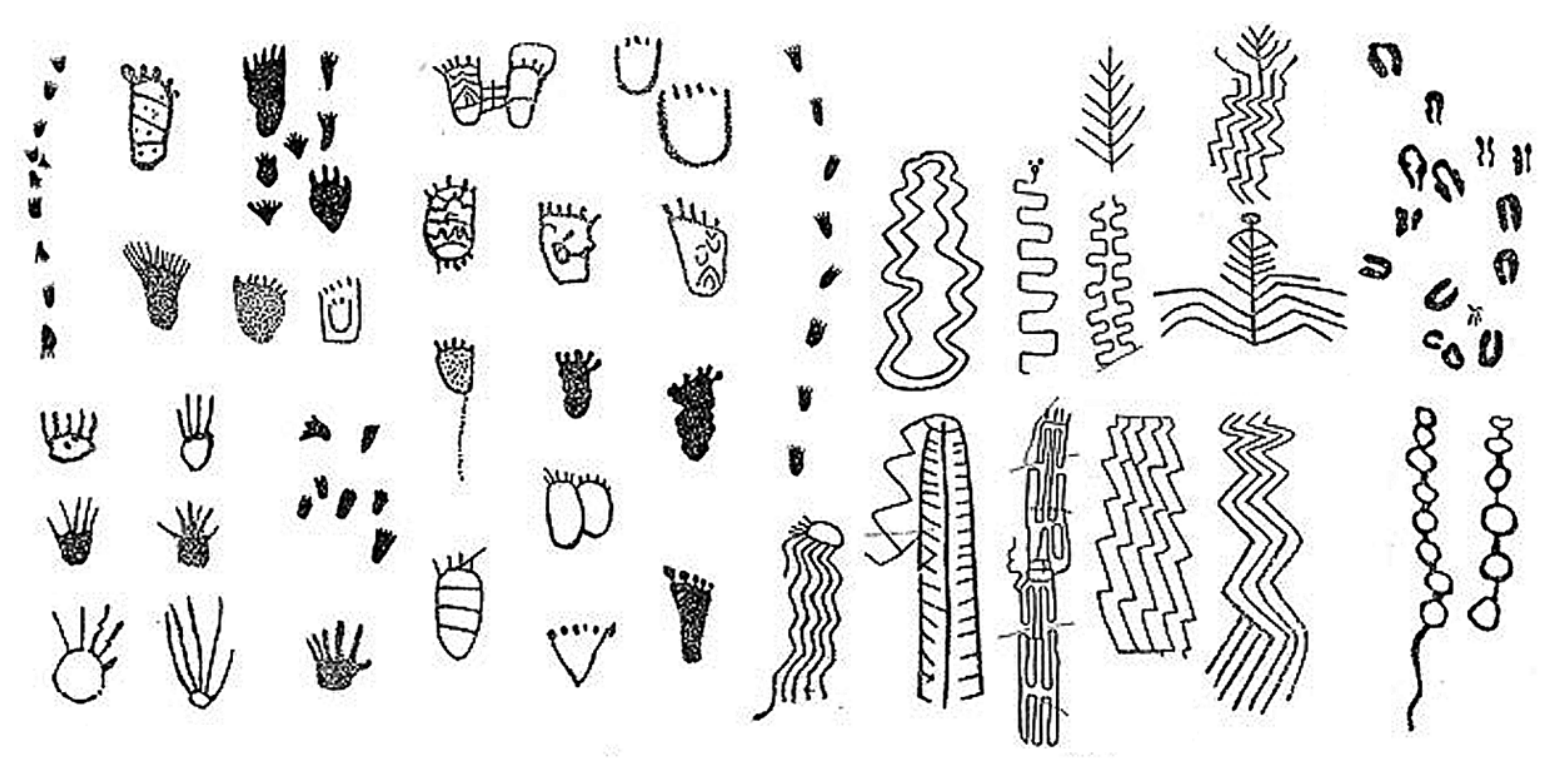

Figura 10. Algunos motivos Guaiquivilo (Mostny \& Niemeyer 1983: 70, 71, 74).

Figure 10. Guaiquivilo motifs (Mostny \& Niemeyer 1983: 70, 71, 74).

\section{EL REDESCUBRIMIENTO DE UN CASO DE ESTUDIO}

Hace más de cuarenta años que comenzó de manera intensiva la prospección y la descripción de sitios arqueológicos al interior de la cordillera de Chile central, cuyo ámbito preferente fue la amplia cuenca del río Maipo. A pesar de su compleja topografía y su clima, su uso prehistórico fue intenso. Dentro de los sitios reportados, los de arte rupestre no constituyeron excepción, a saber: Río Colorado (Niemeyer 1958), Cerro Los Ratones (Madrid 1969, 1977), El Alfalfal (Miranda \& Saavedra 1997) y La Junta (com. pers. L. Cornejo). Con todo, es muy intrigante que la cuenca hidrográfica más importante de la zona central presente solo cuatro sitios rupestres, comparando con su profusión en valles adyacentes al norte y al sur. De los sitios conocidos, el más conocido es Cerro Los Ratones (CLR), registrado por método de calco por Madrid (1969). A pesar de estos trabajos, la localización precisa del sitio se desconocía, habiéndose intentado ubicarlo en varias ocasiones por distintos equipos de investigación. ${ }^{5} \mathrm{La}$ figura 12 es un detalle del panel principal, y la primera a color de este sitio, cuatro décadas después de su descubrimiento. Abajo se presenta el dibujo del mismo panel que resuelve los motivos y rayas del petroglifo, agregando un destacado en rojo y amarillo para señalar algunas superposiciones.

En principio, CLR muestra gran cantidad de grabados rupestres que cuadran bien con la descripción del arte

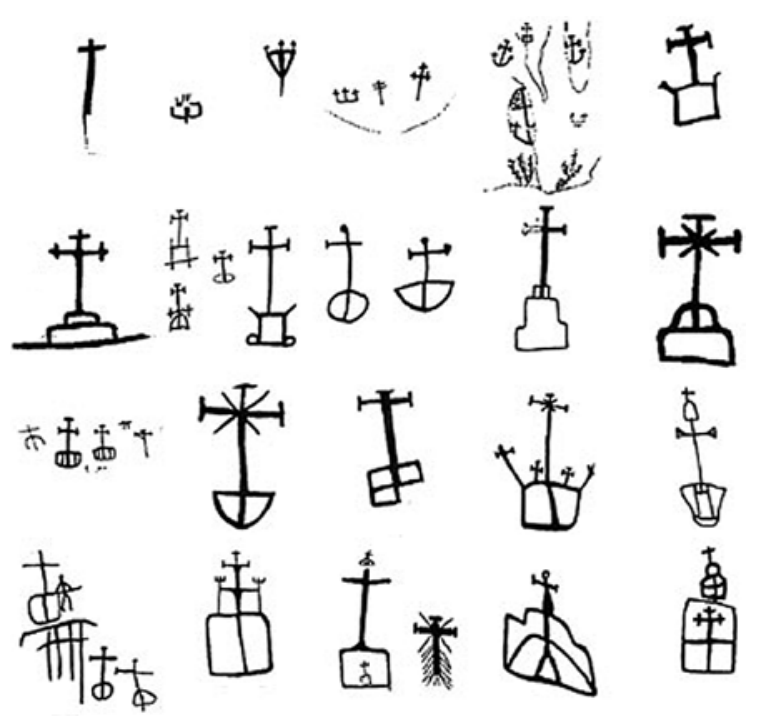

Figura 11. Cruces rupestres coloniales (Hostnig 2004: 60, 62). Figure 11. Colonial era rock art crosses (Hostnig 2004: 60, 62).

prehispánico regional, Estilo I (Troncoso 2001, 2005), cumpliéndose la presencia de figuras preferentemente circulares, trazos lineales simples, yuxtaposición y ordenamiento espacial oblicuo. Pero como se aprecia en la figura, se han impuesto sobre el panel varios motivos y rayas que tienen por propósito la "extirpación" de esta idolatría, proceso colonizador del imaginario bien conocido en el área andina (cf. Martínez 2009). En amarillo, se nota una cruz potenzada como la reseñada por 
Hostnig (2004, ver fig. 11) y en rojo, un repaso posterior que agrega un pedestal o "calvario" y una nueva cruz más simple. ${ }^{6}$

Durante la prospección que realizamos se halló un nuevo sitio que da cuenta de otro proceso de asociación de imágenes, aunque pensamos que de tiempos anteriores. Hemos llamado a este sitio "Los Luchos". El emplazamiento del sitio es visible desde CLR y se encuentra en una situación de paisaje similar, sobre una plataforma rocosa que pende cerca de 300 metros sobre el río Maipo y por donde, presuntivamente, pasaría el camino prehispánico hacia la vertiente oriental de la cordillera. La figura 13 presenta los dos paneles del sitio.

Por último, durante una de las campañas de prospección, al preguntarle a un lugareño, Atilio Vargas, por qué se llamaba al cerro "los ratones", nos contestó que era porque "[...] tiene dibujado un ratón ahí mismo, po, pasaíto el puente". En efecto, existe allí un grabado de proporciones muy grandes, con su interior pintado rojo, que representa un ratón de traza republicana.

\section{DE LA ASOCIACIÓN ICONOGRÁFICA A LA ICONOCLASTA}

El ejemplo anterior (figs. 12 y 13) presenta un caso tremendamente interesante del modo en que distintas entidades culturales inscriben memoria en la piedra, presentándose al menos seis de ellas diacrónicamente, aunque de manera dialógica, en una sola localidad.

Definiremos la primera, genéricamente, como Período Intermedio Tardío, en consideración al grabado de figuras circulares y lineales yuxtapuestas diagonalmente (fig. 12).

En segundo término, aparece el sitio "Los Luchos", que presenta una figura en clara divergencia con los cánones planteados, pues se trata de una figura individual, pero construida sobre una noción del círculo y la curva sumamente claros y preferentes, por contraposición al diseño rectilíneo que cabe esperar. Puede, quizá, interpretarse como una figura "transicional". Respecto de esta representación antropomorfa tridígita, proponemos que se trata de una específicamente Aconcagua tardía, dados estos rasgos. Si se tratase de una representación Diaguita, tendríamos que esperar un mayor énfasis en el ordenamiento vertical-horizontal y simetrías angulares en el diseño (ver p. e., fig. 9, izquierda). Existen símiles estilísticos a esta representación antropomorfa en Río Colorado (Miranda \& Saavedra 1997), en "Las Marcas", en la cordillera del Maule (Vergara 1972-1973: 476) y en el semiárido en San Agustín 6 y Canelillo 19 (Jackson et al. 2002: 39, 46-47). Es interesante notar que
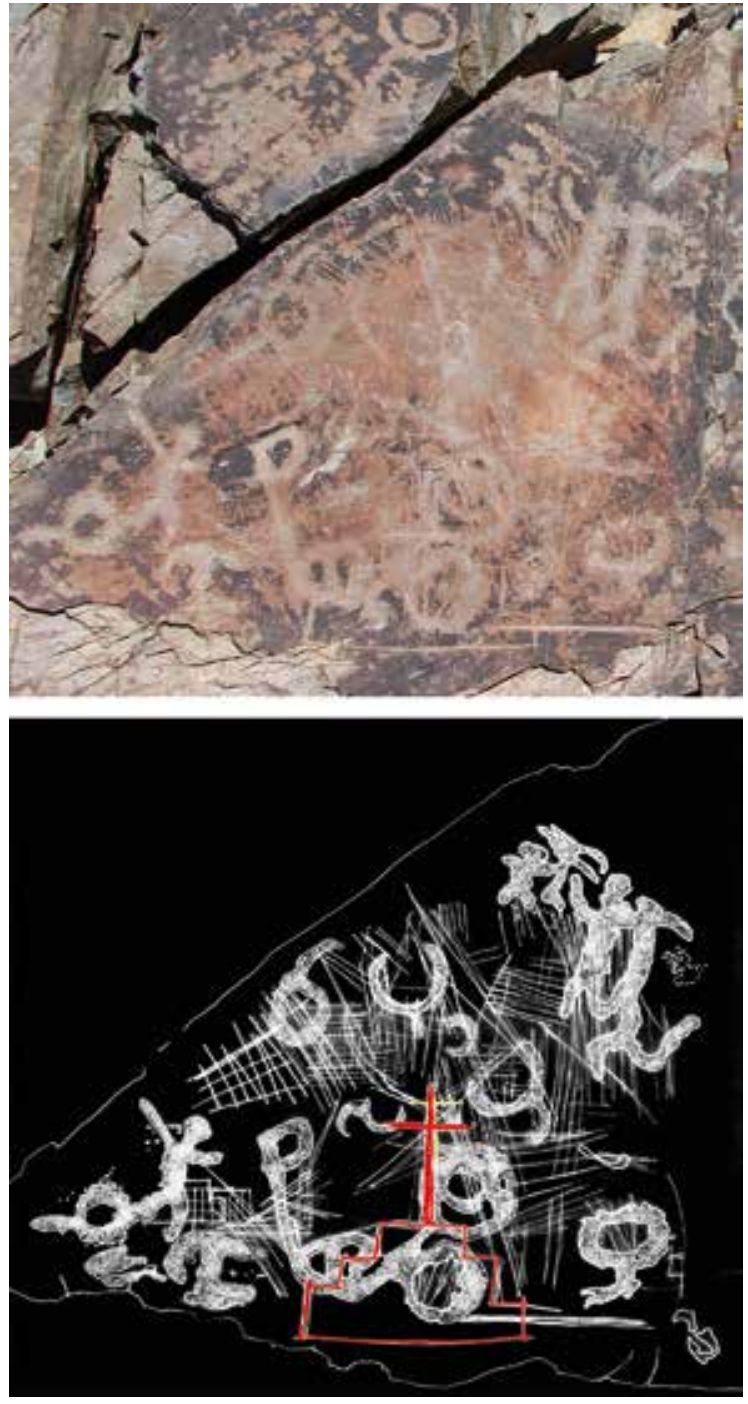

Figura 12. Cerro Los Ratones (CLR), panel 1 y su dibujo (M. De la Maza).

Figure 12. Cerro Los Ratones (CLR), panel 1 and its drawing (M. De la Maza).

el tratamiento tridígito de las extremidades aparece en representaciones en cerámica Diaguita con influencias inkaicas, pero con distintos orígenes y frecuentemente asociados a aves: cusqueño, mixto, Inka-Paya o santamariano, si seguimos a González (2013).

En tercer lugar, tenemos la asociación a la representación antropomorfa de lo que puede entenderse como la representación de un hacha, "canipu", o "huama" según Horta (2008), o incluso la hoja de un yauri (Larrea 1941), todos objetos que pueden ser asimilados a hachas, en tanto emblemas de poder (Nielsen 2007). Esta es de suma importancia, pues el tipo que se ha grabado es un modelo de objeto metálico que no se 


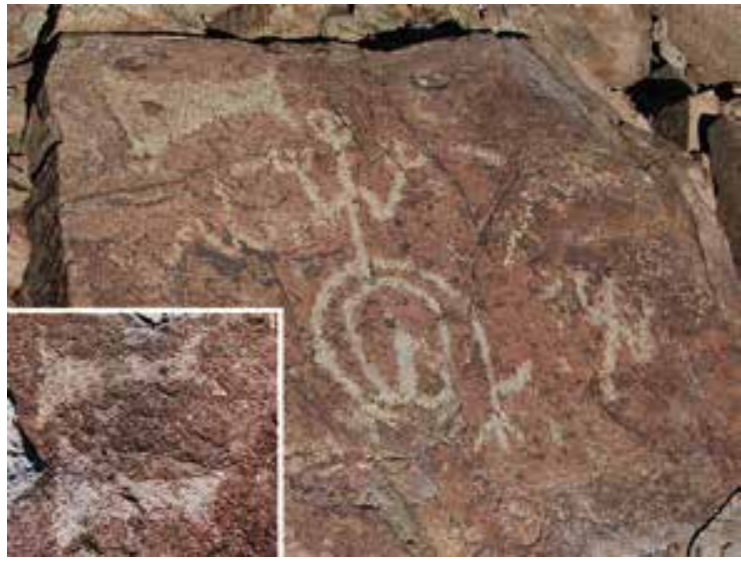

Figura 13. Los Luchos, paneles 1 y 2.

Figure 13. Los Luchos, panels 1 \& 2.

ha registrado para Aconcagua, sino que para Diaguita (ejemplos en las figuras 5 y 9). Pueden hallarse figuras parecidas, denominadas "rectángulos con lados cóncavos", pero dispuestas verticalmente, a veces con la inscripción de círculos (¿orificios de sujeción?) en el río Chicharra, nacientes del Choapa; el río Hurtado (Ballereau \& Niemeyer 1999: 273) y en la costa de Los Vilos (Jackson et al. 2002: 55, 74). El tema de las hachas está presente en distintos registros visuales en los Andes más o menos sincrónicamente en tiempos de conflicto (cf. Nielsen 2007) y lo retomaremos más adelante.

Reforzando la idea de una distinta identidad social en la ejecución de estos motivos, resulta que -examinados de cerca- el antropomorfo de Los Luchos ha sido realizado por percusión lítica directa y las "hachas" han sido agregadas alrededor y en el panel del frente empleando un intermediario metálico con percusión indirecta. ${ }^{7}$ En cualquier caso, los motivos son, por técnica y referente, completamente distintos entre sí, una asociación que más sugiere un proceso de integración, respetuoso de las identidades respectivas, que uno de sujeción violenta.

Este tipo de intervención aparecerá, en cuarto lugar, en la representación de la cruz potenzada (en amarillo en la fig. 12, abajo), y en las abundantes incisiones más finas, sobre todos los paneles de Cerro Los Ratones. Estas han sido realizadas empleando un instrumento metálico de filo agudo y cortante, un cuchillo, seguramente europeo. Esta inscripción es parte de un proceso iconoclasta de dominación.

Dentro del mismo proceso histórico, reconocemos un quinto evento de imposición de imágenes, que es el que repasa la cruz latina anterior y agrega el calvario escalerado que se destaca en rojo en la misma figura. Si seguimos la propuesta de seriación cronológica de
Arenas (2011), estos dos momentos podrían corresponder a finales de los siglos XVI y XVII.

Por último, y en sexto lugar, aparece el ratón pintado de tiempos republicanos y que se encontraría relacionado con una explotación minera en las cercanías. Debe notarse que, según los documentos, el Cajón del Maipo fue explotado desde el Inka (mina Copacabana, Encina en Lagos 1985: 50) y que en tiempos coloniales tuvieron gran importancia las minas de San Pedro Nolasco, a escasos kilómetros, que entregaron gran renta en impuestos durante la Colonia tardía. La fundación de San José de Maipo en 1792 tiene que ver con el control de estos recursos argentíferos. Domeyko hace una descripción de la ruta en su viaje de 1841, dándonos la posición casi exacta del Cerro Los Ratones (cf. Ryn 2000).

Estos datos y la narración que nos presenta este contexto pueden entenderse como probablemente ligadas a los metales y la minería, siendo atendible el planteamiento de Llagostera (1976: 217), según quien desde tiempos inkaicos, en la región "[...] se puso de manifiesto un complicado sistema agrominero, en el que entraron en un juego complementario los núcleos mineros y los núcleos agrarios, siendo estos últimos los nutrientes de los primeros", hipótesis que -conviene recordar- apoyan con matices Cantarutti (2002) para el norte semiárido, y Ávalos \& Saunier (2011) para el Aconcagua inferior.

\section{LA FRONTERA SEPTENTRIONAL. IMÁGENES, OBJETOS Y TEXTOS}

Hasta aquí hemos visto cómo se produce en lo rupestre un proceso de inscripción de memoria no mediado por la escritura, sino que por la representación de objetos que pueden ser muy diagnósticos de filiación cultural. A veces, una imagen dice más que mil palabras. A continuación avanzaremos de Chile central al sur, comparando arte rupestre, objetos arqueológicos y algunos textos que los describen en uso.

\section{Hachas, escudos "y rectángulos de lados cóncavos"}

En términos generales, admitimos la tesis de Troncoso (2001, 2004) de que los "signos-escudo" son de tiempo Tardío y que podrían emular "tocapus" inkaicos. Pero desde nuestra perspectiva, algunos de ellos no son otra cosa que "signos-hachas" (toki-cura y toki-manos), objeto arqueológico muchísimo más frecuente que los escudos en la región, identificadas a la usanza inkaica quizá en un proceso de reacción a su influencia. Pueden 


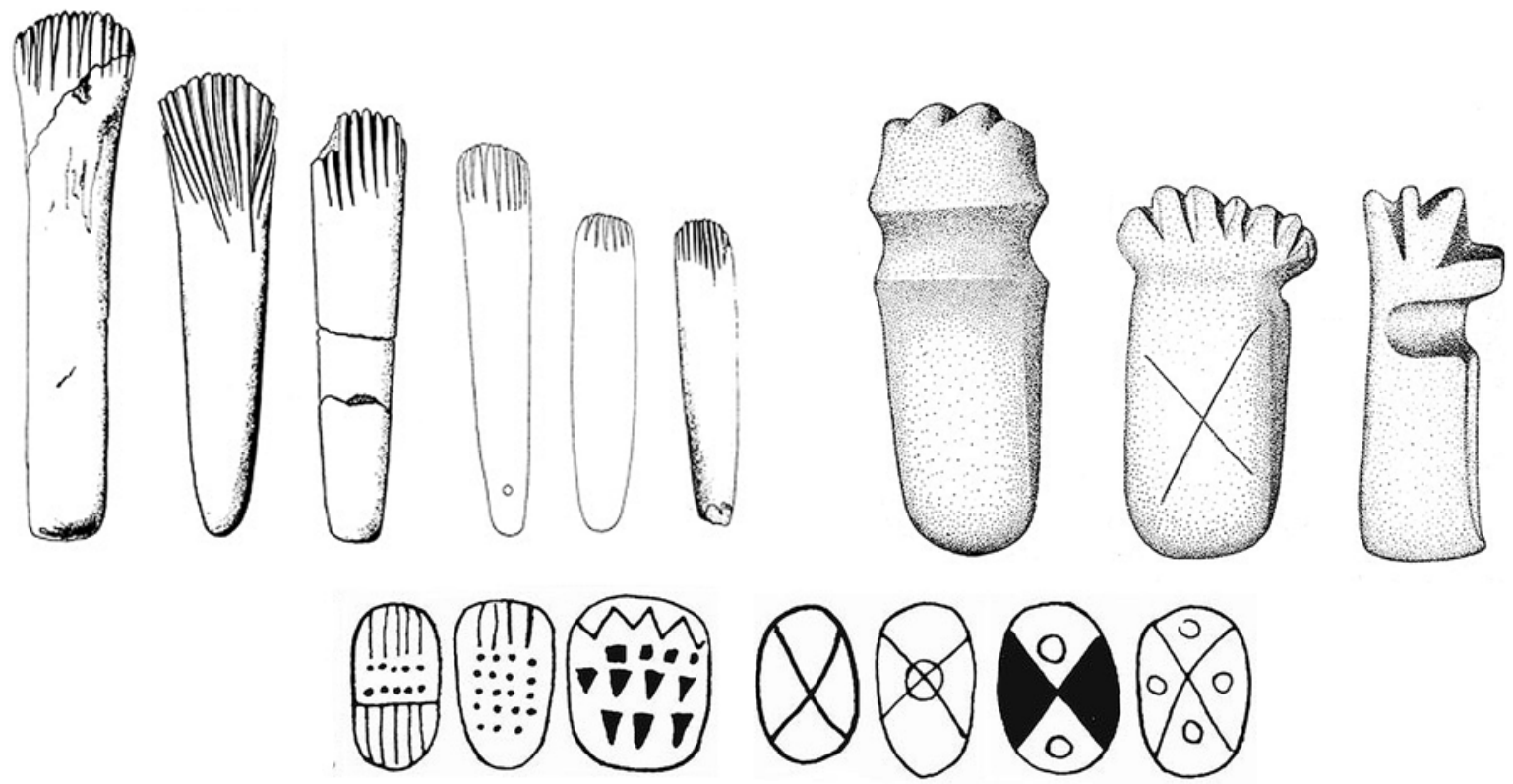

Figura 14. Comparación entre algunos signos escudo y objetos arqueológicos. Valenzuela (1964: 168-169), Iribarren (1969: 42-43) y Mostny \& Niemeyer (1983).

Figure 14. Comparison of shield signs and archaeological objects. Valenzuela (1964: 168-169), Iribarren (1969: 42-43) and Mostny E Niemeyer (1983).

esbozarse algunos ejemplos de "signos-escudos" y sus referentes materiales (fig. 14). Nótense los tres primeros "signos", abajo, con ranurados distales en comparación con las toki-mano (arriba izquierda); los restantes hacen alusión a la clave inka, tal como la toki-mano a la derecha y centro, de Coquimbo. ${ }^{8}$ Se ha reportado también un hacha metálica de esta forma general, aunque sin ranurado, para la huaca-fortaleza inkaica del cerro Chena (Stehberg 1977). ${ }^{9}$

Por otra parte, resaltan en el semiárido los "rectángulos de lados cóncavos", de los cuales algunos presentan atributos antropomorfos como ha sido presentado por Troncoso (2011). Estos serían símiles de algunas "figuras con vestimenta" ("escutiformes") de mucho más al norte (Atacama y Noroeste Argentino), más o menos al mismo tiempo que el conflicto interétnico, durante la "Edad de Indios Auca Runa" (ver p. e., Nielsen 2007; Berenguer 2009a) y con continuidad hasta tiempos Tardíos. Montt \& Pimentel (2009) entienden algunos de ellos como "personificaciones de hachas" en lugar de escudos. ${ }^{10}$

$\mathrm{Al}$ respecto, Troncoso (2011: 223) señala que es una "[...] idea altamente sugerente, dadas no solo las asociaciones reconocidas entre ambos tipos de diseños en diferentes soportes, sino también por la cercanía representacional entre ambos, producto del hecho de compartir un rasgo diagnóstico: la muesca medial que genera lados cóncavos".

Pero la mayor parte del registro en el norte semiárido y ahora "Los Luchos" en el río Maipo en Chile central, no presenta atributos anatómicos humanos (v. g., cabeza y piernas), pero sí atributos de "insignia" (agujeros de sujeción o disposición vertical). De esta manera, es factible interpretarlos como hachas o canipus. Debe notarse, en todo caso, que las del semiárido tienden a presentar decoración interior, aunque no siempre.

\section{Los quipus}

No es desconocido el arraigo de este sistema mnemotécnico entre las poblaciones indígenas de Chile, por cuanto incluso el Estado español lo permitió y empleó, como ocurrió en el norte semiárido:

Ordenanza $\mathrm{N}^{\circ}$ 25: Que no consienta que en el tambo de su pueblo estén más de un día los pasajeros y si estuvieran más no les den recaudo y de lo que en el dicho tambo se consumiere asiente para dar cuenta, con pena que no lo haciendo lo pagará de su hacienda y asimesmo el indio tambero tenga quipo de el dicho consumo y gasto y que el corregidor de el partido le tome cuenta cada mes con cuidado, en presencia de el indio tambero y firme las dichas cuentas al pie dellas y si no pudiere cada mes, sea lo más presto que pudiere (Iribarren \& Bergholz 1972-1973: 261). ${ }^{11}$ 
Para el caso sureño, es excelente el ejemplo de Alonso González de Nájera (1971 [1614]: 98):

Lleva el mensajero una cuerda a que llaman yipo, de tantos nudos cuantos días han de tardar los indios en venir a juntarse en el puesto que se les declara; para lo cual van deshaciendo cada día un nudo, contando los que faltan para conforme ellos medir el tiempo de sus jornadas y ajustar el en que han de llegar al lugar señalado. ${ }^{12}$

Más tarde, Amadeo Francisco Frézier (1902 [1716]:4243), ingeniero francés, relata cuanto vio respecto del quipu entre 1712 y 1714 en la costa sur de Chile, especialmente Talcahuano:

Para llevar la cuenta de su ganado i conservar el recuerdo de sus asuntos particulares los indios recurren a ciertos nudos de lana que por la variedad de los colores i de los pliegos reemplazan las letras i la escritura. El conocimiento de esos nudos llamados quipos es una ciencia i un secreto que los padres revelan a sus hijos cuando creen que llega el término de sus días i como a menudo sucede que faltos de espíritu, no comprenden el misterio, esas especies de nudos se convierten en error y caen en desuso. Para suplir la falta de escritura encargan a los que tienen escelente memoria, el cuidado de aprender la historia del país i de recitarla a los demás. Así es como conservan el recuerdo de los malos tratos que los españoles han dado a sus antepasados, cuando los subyugaron, lo que perpetúa el odio que tienen a ellos. ${ }^{13}$

En 1853-1854, otro viajero, William Bollaert (1860: 185-186), escribe, citando a Stevenson, una extraordinaria relación del modo de su uso entre los "araucanos":

\begin{abstract}
Stevenson da lo siguiente en relación al Quipo: en 1792 tuvo lugar una revuelta cerca de Valdivia y, en el juicio de los cómplices, Maricán, uno de ellos, declaró que la señal enviada por Lepitrarn era una pieza de madera, que al ser partida se halló que contenía el dedo de un Español; que estaba envuelto alrededor con un cordel con un borde en un extremo, hecho de lana gruesa roja, negra, azul y blanca; que en la negra habían sido amarradas por Lepitrarn cuatro nudos, para intimar que era el cuarto día después de la luna llena cuando el portador había salido de Paquipulli [Panguipulli]; que en la blanca había diez nudos, indicando que diez días después de esa fecha la revuelta tomaría lugar; que en la roja debía anudarse, por la persona que la recibiera, un nudo si asistía a la revuelta, pero si se negaba, debería amarrar juntas con un nudo la roja y la azul; de este modo, de acuerdo a la ruta tomada por Lepitrarn, pudiese descubrir al retorno del mensajero, cuántos aliados se le unirían; y si disentía, él pudiera saber quién era por el lugar donde el nudo que unía ambos cordeles estaba atado. Así, parecería que los Toquis de Arauco pueden preservar registros por medio de una suerte de Quipo, que podrían haber obtenido originalmente del Perú. ${ }^{14}$
\end{abstract}

La similitud entre algunos motivos del arte rupestre del sur de Chile y los quipus ya había sido señalada por Jaffuel (1930), para el río Los Cipreses. Algunos de los referentes que cuadran con estas descripciones se encuentran en la figura 15 , donde las imágenes de la derecha hacen referencia general a la "anatomía" de

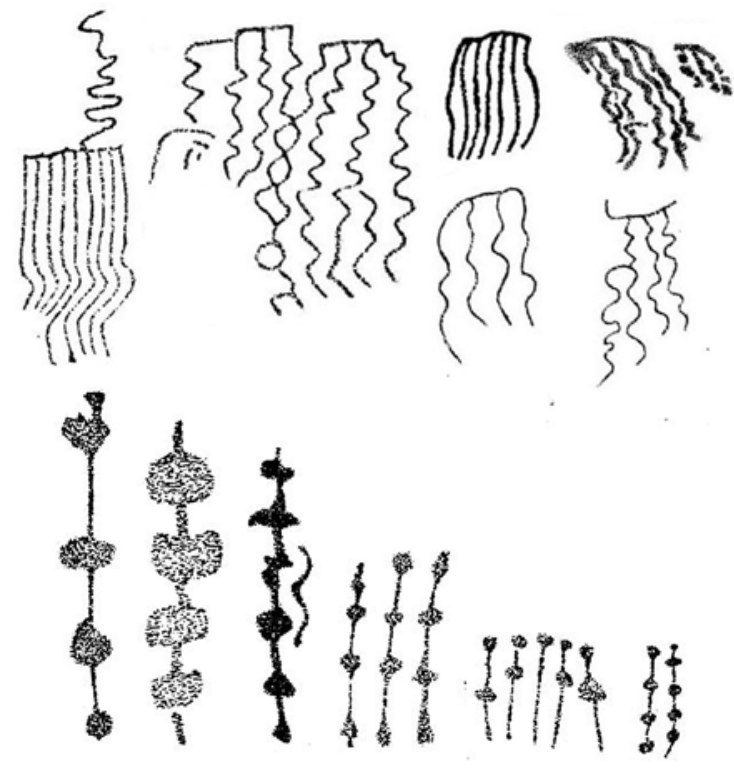

Figura 15. Posibles quipus y nudos Guaiquivilo. En Niemeyer \& Weisner (1972-1973: 438, 440, 442, 452, 457, 460, 463) y Niemeyer \& León (2001: 60).

Figure 15. Possible Guaiquivilo quipus and knots. Niemeyer $\varepsilon$ Weisner (1972-1973: 438, 440, 442, 452, 457, 460, 463) y Niemeyer ELeón (2001: 60)

un quipu y las de abajo pudieran añadir los necesarios nudos a la discusión.

\section{La chicha... y el maíz}

Un aspecto acerca del que se ha llamado la atención frecuentemente en la literatura arqueológica es la introducción de nuevos tipos cerámicos y decoraciones en la ergología de los grupos que el Estado inka "anexionaba”. El ejemplo más señero lo constituye el aríbalo o "aribaloide", en sus versiones provinciales, con asociación exclusiva al transporte de chicha de maíz para la celebración de fiestas en las que se manifestaba la reciprocidad del Estado para con los señores y la población local.

Pero existen otros artefactos relacionados con la libación. Frézier (1902 [1716]: 31-32) nos entrega un dato valiosísimo a la hora de ponderar la penetración del consumo de esta sustancia entre los "araucanos", al ofrecernos una narración de una fiesta en Talcahuano en 1712 :

Las mujeres les dan a beber chicha, una especie de cerveza... en un aparato de madera de dos $i$ medio pies de largo, compuesto de una taza con oreja al lado $i$ un largo pico al otro, abierto con un pequeño canal en forma serpentina, a fin de que entre suavemente a la boca por un agujerito en el fondo de la taza. Con este aparato se embriagan como animales, cantando sin 
interrupción i todos juntos, pero con canto tan poco modulado que tres notas bastarían para esplicarlo.

La, Si, Do | La, La, Si, Do | La, La, Do | La, La, Si, Do | La

Las palabras que cantan no tienen rima ni cadencia, i ni otro asunto que el que les viene en antojo, ya sea la bistoria de su antepasado, de su familia, o los motivos por qué celebran la fiesta, o de la persona por quien se efectúa, etc. ${ }^{15}$

Este fragmento no describe otra cosa que una libación realizada mediante una pajcha ceremonial, artefacto típicamente tardío (de tiempos inkaicos), en sus versiones cerámicas; con modelos muy bien conocidos para el Cusco en la Colonia, manufacturadas en madera, objeto que identificamos entre el arte rupestre del Cajón de Valdés.

La figura 16 presenta lo que entendemos como una pajcha, en vista cenital, dibujada por Niemeyer y Weisner (1972-1973), nótese la acanaladura central zigzagueante en el vástago que se desprende hacia abajo y compárese con los ejemplos prehispánico y colonial al costado. Es extraordinariamente interesante notar que el receptáculo presenta una cabeza humana, similar a las representaciones Llolleo y Pitrén (ver fig. 3) y que, aún más, tiene bajo la boca un tembetá. Debido a su similitud general incluimos la pajcha cefalomorfa, en cerámica, del Estadio Fiscal de Ovalle (cf. Cantarutti 2002: 38), en el norte semiárido. Recientemente se ha encontrado el fragmento apical de una de estas piezas en el cerro Mercachas, río Aconcagua, fragmento de filiación Diaguita que exhibiría una pintura zigzagueante que simularía el surco. Por cierto, la imagen rupestre comparte atributos de las pajchas arqueológicas y las coloniales.

También, el grabado que acompaña la edición original francesa de la obra de Frézier (1716) incluye una imagen (fig. 17), donde a los pies de un jugador de chueca se advierte una pajcha señalada por la letra $\mathrm{F}$ y al pie de lámina la inscripción Paquecha ou tasse a bec.

Si la imagen del arte rupestre es una pajcha, no es difícil interpretar algunos fitomorfos de la cordillera de Linares y del Cajón del Maipo (Miranda \& Saavedra 1997), como representaciones del maíz. Compárese las imágenes de decoraciones en "helecho" en piezas arqueológicas (fig. 7), versus las figuras fitomorfas del Estilo Guaiquivilo (fig. 18). Esta asociación ha sido planteada por Troncoso (2006a: 178).

Existen aún otras imágenes que pueden ser de raigambre andina y que estarían asociadas a la producción agrícola, quizá del maíz mismo. Se han denominado "maquetas" y se trataría de representaciones de áreas de cultivo, fuentes de agua y canales, y han sido reportadas para el río Salado, Chile (Gallardo et al. 1999), y el
Noroeste Argentino (Aschero et al. 2009). La figura 19 compara este último registro, a la izquierda, con los de "retiformes" de Niemeyer y Weisner (1972-1973) para la cordillera sur.

\section{SIINTESIS Y CONCLUSIONES}

Si bien nos sentimos tentados a admitir como válidas las asociaciones planteadas en las secciones precedentes, no podemos hacer otra cosa que aconsejar cautela y tomarlas como hipótesis que investigaciones más profundas y detalladas podrán probar o, en definitiva, refutar. A continuación, entregamos una apretada síntesis de los puntos más salientes de este breve ensayo sobre las "otras memorias", como cabe llamarlas.

Existe continuidad iconográfica regional, desde tiempos tempranos hasta el Estado inkaico, como se desprende de la equivalencia de diseños que están presentes en Bato y Llolleo, Pitrén, Aconcagua y Mapuche. Los motivos perviven más de mil años y se adaptan a la nueva situación que propone la presencia del Inka en la región. En este sentido es que decimos que existe, primero, contacto y, luego, integración.

Parece ser que los "signos-escudo" podrían representar hachas de piedra Aconcagua y los "rectángulos de lados cóncavos" a hachas o cuchillos metálicos, e incluso "insignias", que proponemos como formalmente derivadas de hachas, de filiación Diaguita (ver figuras 5 y 8). En ese sentido, nuestro ejemplo "Los Luchos" sugiere que pudo haber una ocupación minero-agraria tardía en el curso alto del río Maipo, posiblemente con elementos Diaguita. La hipótesis de Llagostera (1976) se sostiene con este ejemplo. ¿Habrá movilizado el Inka población minera -portadora de la tradición estilística "Limarí", con agregados de contacto- desde más al norte para sus faenas en el alto río Maipo? Estas son cuestiones que requieren más investigación.

Como fuera, el Inka tuvo mucha mayor influencia espacial de la esperada de acuerdo con los documentos. Se encuentran suficientes casos de representaciones de objetos inkaicos o locales con influencia inkaica en y al sur del río Maule, lo que ofrece apoyo a la tesis de Dillehay y Gordon (1995). Si consideramos que similar argumento ha sido hecho para el límite inkaico en Cuyo por García (1997), a la vista de documentos y de objetos arqueológicos, moviendo la frontera del río Mendoza al Diamante (Cachapoal en la vertiente chilena), para la completitud del territorio Huarpe, no resulta difícil validar esta tesis. Es importante recordar el caso de la cerámica Vergel, mucho más al sur (Bahamondes 2009, 2010). 
a
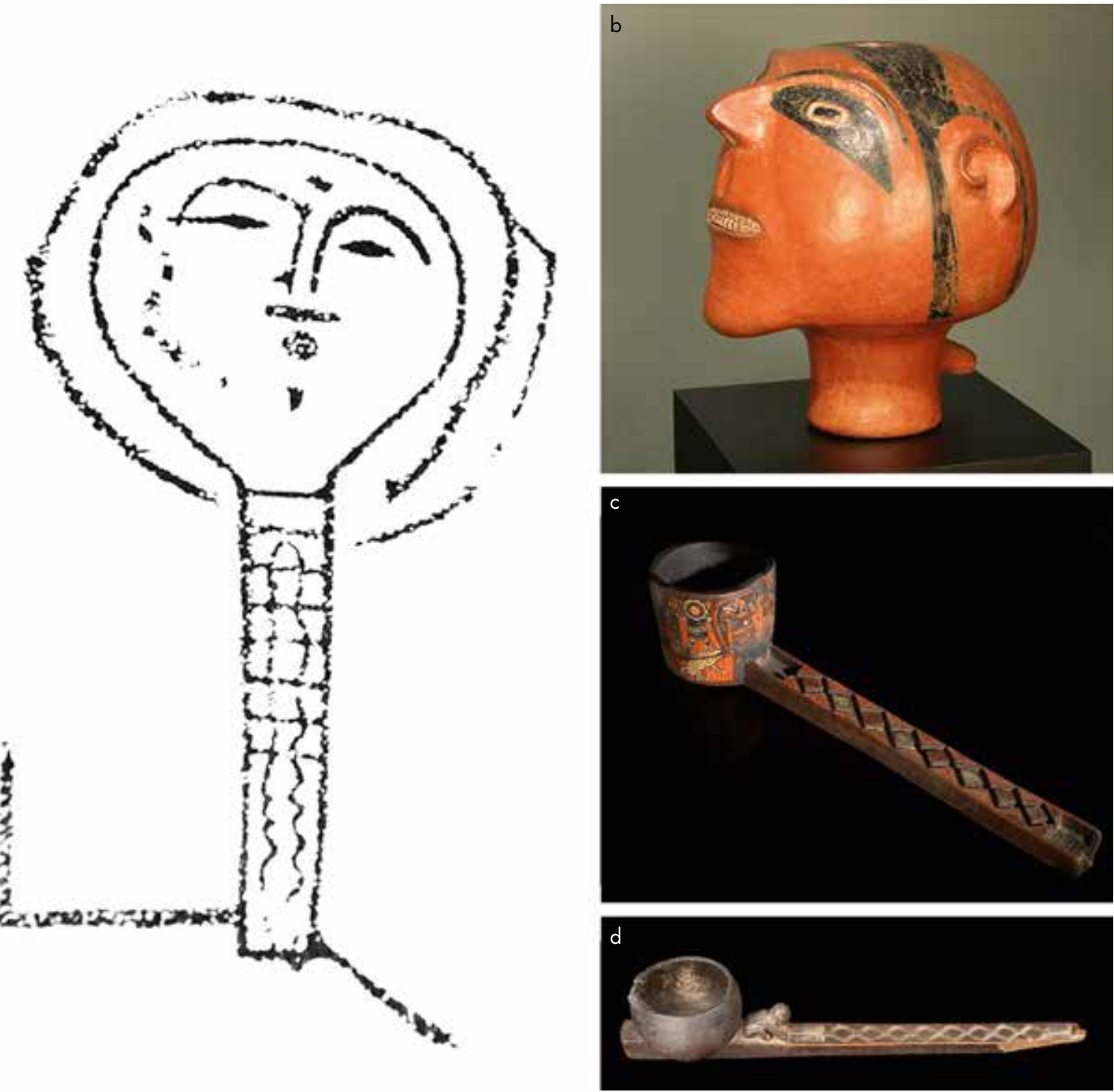

Figura 16. Arte rupestre del Cajón de Valdés y pajchas ceremoniales: a) Grabado de Niemeyer \& Weisner (1972-1973: 431); b) Estadio Fiscal de Ovalle (Berenguer 2009b: 78); c) National Museum of the American Indian (pieza 15/2410); d) Museé du quai Branly (pieza 71.1968.12.1.).

Figure 16. Rock art of the Cajón de Valdés and ceremonial pajcha receptacles: a) Sketch by Niemeyer E Weisner (1972-1973: 431); b) Estadio Fiscal de Ovalle (Berenguer 2009b: 78); c) National Museum of the American Indian (piece 15/2410); d) Museé du Quai Branly (piece 71.1968.12.1.).

La situación iconográfica entre desarrollos regionales e inka es radicalmente distinta a la que ocurre con la llegada de los españoles y su institución de extirpación de idolatrías a partir de 1574 , desde el virrey Toledo (Martínez, J. L. 2009). Es aquí cuando conviene hablar de dominación. En este sentido, hemos presentado un nuevo-viejo caso de estudio, Cerro Los Ratones, en que este proceso es legible, con una "genealogía" más larga que la de Toro Muerto (Martínez \& Arenas 2009; Arenas 2011) o
Casablanca 33 (Troncoso 2005), en que distintas sociedades inscriben memoria en un mismo lugar. Con esta descripción se ha desplazado la presencia de representaciones de hachas metálicas ("rectángulos de lados cóncavos") mucho más al sur que lo indicado por Ballereau y Niemeyer (1999) -el Choapa- y, al mismo tiempo, la frontera meridional del proceso iconoclasta hispano hasta el río Maipo. Habría que revisar las cruces que menciona Jaffuel (1930: 243) para el río Los Cipreses. 


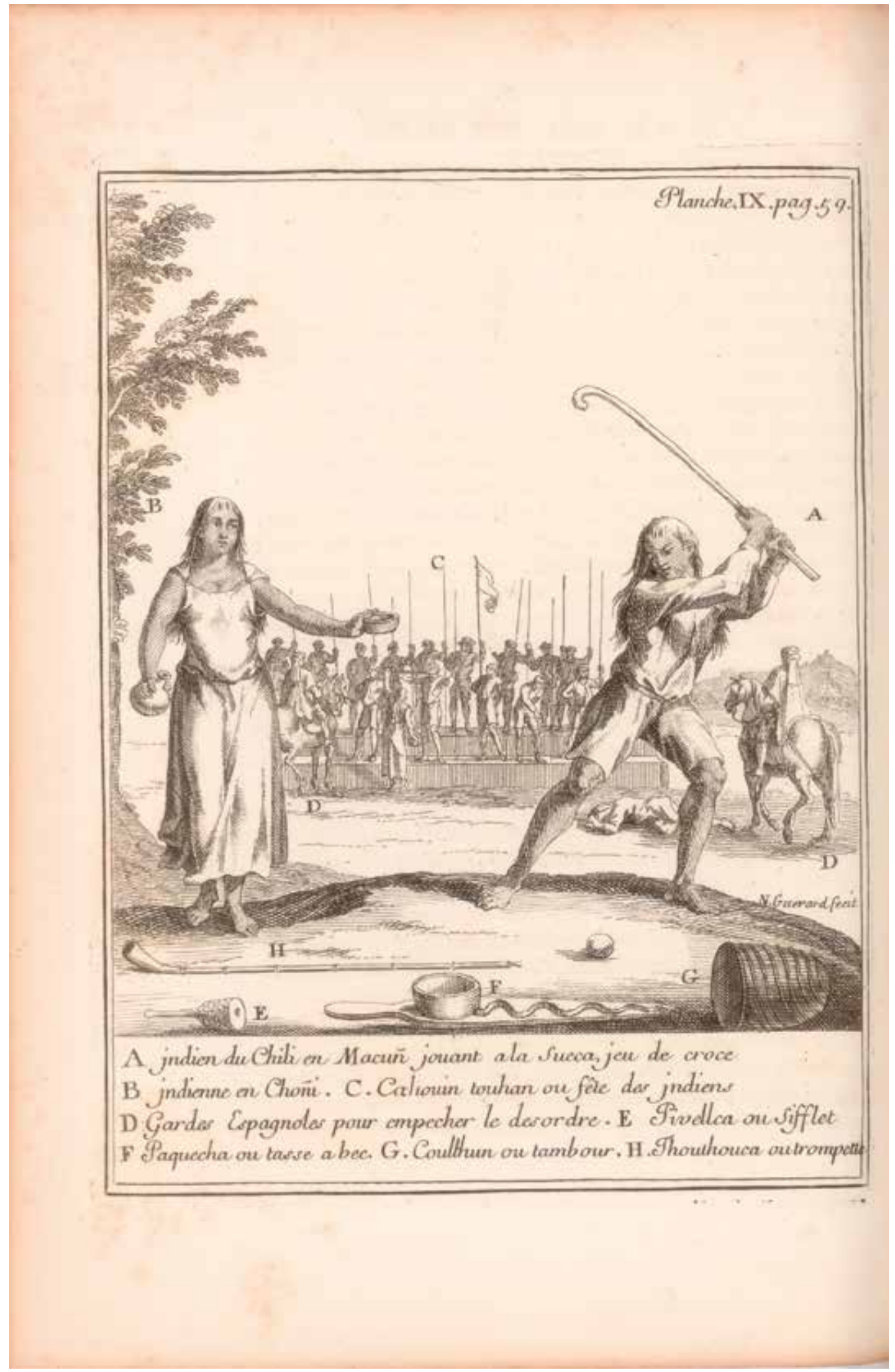

Figura 17. El juego de la chueca, en Frezier (1902 [1716]).

Figure 17. The game of chueca, in Frezier 1902 [1716]. 


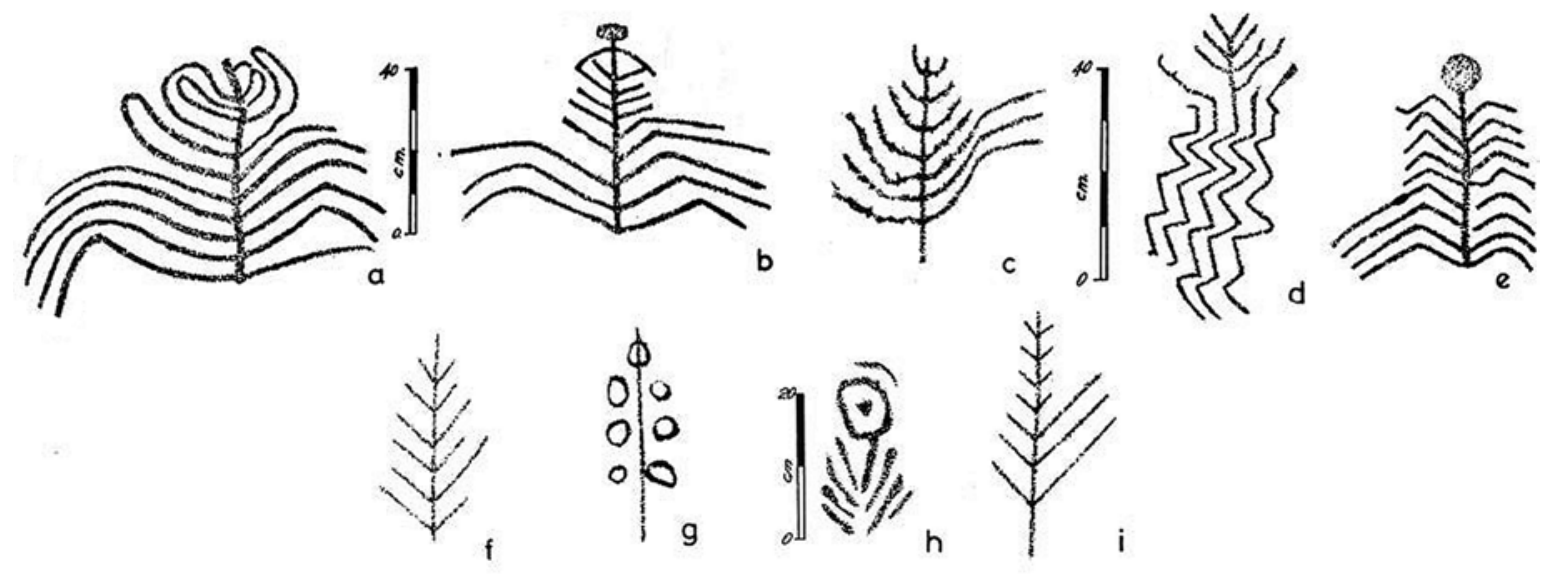

Figura 18. Fitomorfos Guaiquivilo (Niemeyer \& Weisner 1972-1973: 432).

Figure 18. Guaiquivilo plant motifs (Niemeyer \& Weisner 1972-1973: 432).
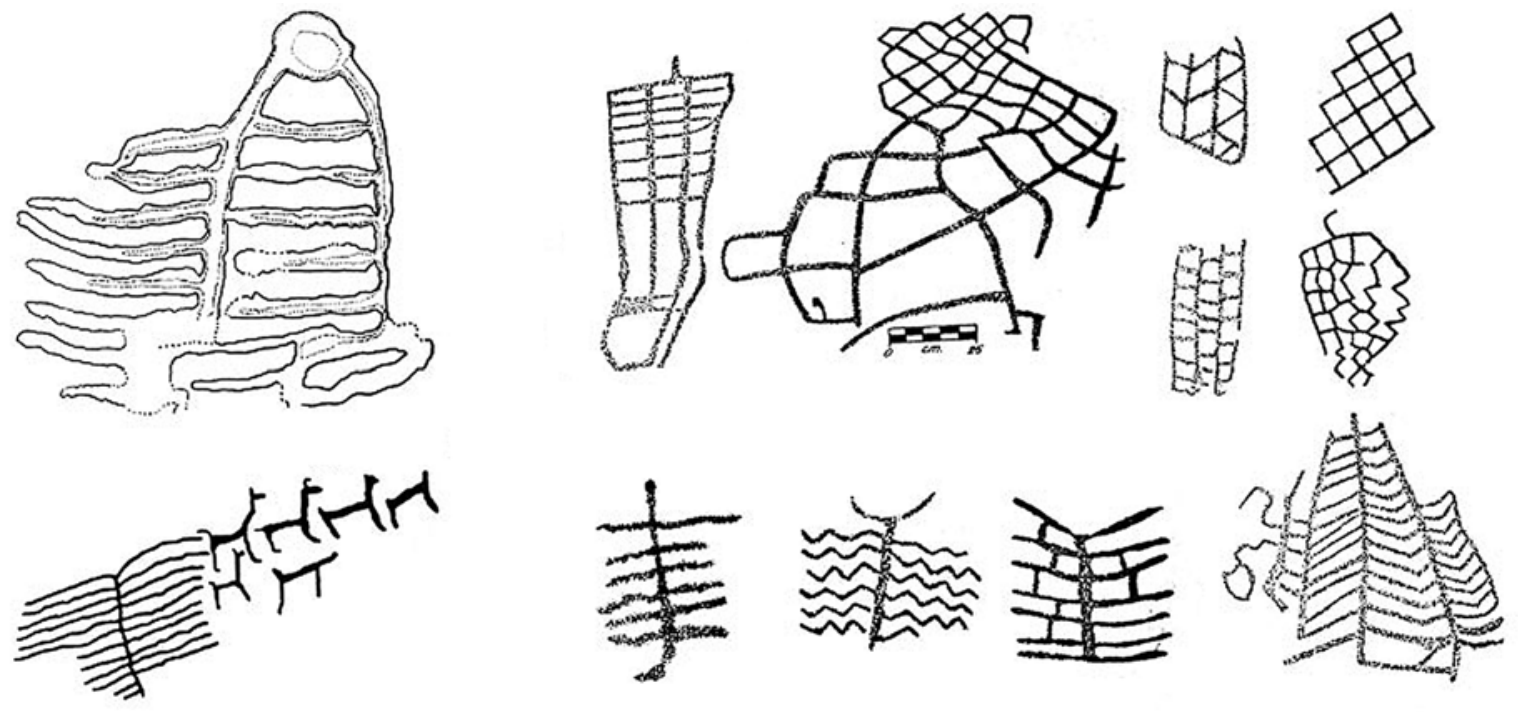

Figura 19. Maquetas versus retiformes. Izquierda, Aschero y colaboradores (2009: 261); derecha, Niemeyer \& Weisner (1972-1973: 448). Figure 19. Models and reticular shapes. Left, Aschero et al. (2009: 261); right, Niemeyer E Weisner (1972-1973: 448).

Sin duda, la propuesta de "andinización" sureña (Dillehay \& Gordon 1995; Dillehay 2007) encuentra posterior sustento en el examen del arte rupestre relevado por Niemeyer y Weisner (1972-1973) en la cordillera del Melado y se ve refrendada por la permanencia en la región de objetos de filiación inkaica, como se advierte del examen de los relatos de viajeros presentados, entre 1600 y 1800. Existieron en la zona mapuche pajchas ceremoniales y quipus que atestiguan esta conexión, aunque falte por el momento recuperar objetos arqueológicos que refuercen la idea.

Es patente que alguna parte del conjunto de significantes visuales de estas sociedades simplemente "recoge" o "copia" lo que ve, como cuestión inherente a los modelos figurativos de que dispone. Pero otra parte posee una dimensión en que comunica y reflexiona, en tanto quienes lo ejecutan saben de la trascendencia en el tiempo y la permanencia en el lugar que esa inscripción supone. En este sentido, sin duda, habría que establecer con mayor detalle las continuidades y las rupturas en cada uno de los sitios que aquí se comentan. En especial, creemos que Cerro Los Ratones se presta muy bien para esta clase de análisis, por ejemplo, como han mostrado brillantemente Martel y colaboradores (2012), para Antofagasta de la Sierra o Armstrong (2012), para un caso en el norte semiárido de Chile. 
En efecto, varios de los significantes que se han discutido han sido descritos como emblemas de poder. Nosotros preferimos verlos, en general, como indicadores de interacción, que puede o no ser violenta. Otros motivos presentados pertenecen a distinto ámbito de cosas, más positivo, que adopta prácticas y cultura material, útiles mejoras, aunque transporte también otras complejidades. Pero ¿por qué pajchas (chicha), maíz, quipus, campos de cultivo? Porque forman parte de un complejo sistema de trabajo y relaciones, un modo de producción de raigambre andina, que es orgánico en sí y en el que cada parte es infaltable. Seguro que hubo una lectura local del ceremonialismo del maíz en cada lugar donde se implementó, sea o no visible arqueológicamente por el momento. En todo caso, nosotros no caracterizaríamos el fenómeno, para el caso de Chile centro-sur, como de relaciones de poder y control inkaico sobre las poblaciones locales -según se indica frecuentemente-, sino más bien como de relaciones sociales y de lo que uno acepta de un otro, sencillamente.

Chile centro-sur fue, a no dudarlo, un territorio de fronteras flexibles y permeables a distintas entidades socioculturales -quizá "interdigitadas"- tanto durante la prehistoria como en tiempos históricos y existe la posibilidad de rastrearlas, ya sea tratando a estas "otras memorias" como equivalentes a los textos o bien tomando a estos como objetos de la misma categoría que los artefactos que analizamos. Como "leer es para ellos" (Cummins 1998), es preciso balancear el sesgo del conquistador que disocia -mediante el libro y la palabra escrita- tiempo y espacio, como si ambas categorías estuviesen separadas en la realidad, máxime en las sociedades andinas. Baste para ello examinar, por ejemplo, los alcances del concepto "pacha" en aymara (Bertonio 1984 [1612]) para entender que no son disociables en lo andino y que, parafraseando a Mignolo (1992), además, siempre es preciso tener un lugar para decir. Quienes inscribieron estas memorias sabían, mucho mejor que nosotros, que la memoria más larga y concisa es la de la piedra.

RECONOCIMIENTOS A J. L. Martínez por su introducción al tema en el seminario de posgrado "Escritura y otras memorias en las sociedades andinas coloniales", dictado en Tilcara a finales del 2010; A. Reyes, por su aporte en terreno; F. Gallardo, G. Cabello, I. Correa, F. Bahamondes y J. Berenguer por sus aportes bibliográficos, y E. Latorre por su apoyo con imágenes. A los tres evaluadores anónimos, por sus importantes comentarios. A los editores, por todas sus gentilezas

\section{NOTAS}

1 "Por sostener un ruego de ayer, diez nudos en pares llevo". Este fragmento forma parte del diálogo Hualonkokuel, un ritual de sanación mapuche, narrado por la machi Juanita (Dillehay 2007: 423). La traducción mapuche-español es de María Catrileo, del español al inglés por P. Netherly y de vuelta al español, nuestra.

${ }^{2}$ La traducción es nuestra.

${ }^{3}$ Las excepciones a esto podrían constituirlas los litos poligonales del Complejo Huentelauquén (Arcaico temprano, ca. 10000 AP [Llagostera et al. 2000]), formas que pudieran entenderse como referentes decorativo-iconográficos, pero que no se reproducen en otros soportes ni reaparecen en complejos culturales posteriores. Tampoco han sido estudiados desde una perspectiva iconográfica.

${ }^{4}$ Pueden seguirse los argumentos en el artículo de Troncoso y colaboradores (2008) y sus comentarios.

5 Comunicación personal de R. Stehberg y L. Cornejo, respectivamente.

${ }^{6}$ Estos dibujos no habían sido informados por Madrid (1969). Es muy extraño que no se hayan detectado con ocasión del calco de los dibujos.

7 Se observaron microscópicamente los negativos de impacto sobre la roca, empleando una lupa de geólogo Hastings triplet Bausch \& Lomb de $10 \mathrm{X}$. La forma y la homogeneidad de los negativos indican un intermediario, que pudiera ser un cincel

${ }^{8}$ Debe destacarse que Gerónimo de Bibar (1966 [1558]) describe una rebelión violenta de los locales ante el Inka en Coquimbo, a propósito de haberse negado los naturales a la construcción de una acequia.

9 Stehberg nos ha indicado que se trataría de una "miniatura" (com. pers. 2011). Consideramos el ejemplo de relevancia para mostrar la asociación Aconcagua-Inka.

${ }^{10}$ Intuimos, aunque no ahondaremos en ello, que este proceso (quizá pueda llamársele "ciclo" narrativo, sensu Martínez [2009]), se extiende a las representaciones de tumis (cuchillos ceremoniales), tema poco explorado.

${ }^{11}$ Instrucciones y ordenanzas para los administradores de pueblos de indios dictados por el gobernador Martín García Ortiz de Loyola, 4 de febrero de 1593. José T. Medina, t. 95, doc. 1430, p. 22-44. Las cursivas son nuestras.

12 Este autor presenta también un ejemplo de su propia defensa de un fuerte contra Nabalburi, en el río Biobío (p. 101). No lo reproducimos por economía de espacio.

${ }^{13}$ Empleamos aquí la traducción española de Nicolás Peña (1902).

${ }^{14}$ La traducción, los corchetes y las cursivas son nuestras.

15 Las cursivas son nuestras.

\section{REFERENCIAS}

Aldunate, C., 2009. Mapuche. Semillas de Chile. Bogotá: Museo Chileno de Arte Precolombino / Banco de la República.

Allen, C., 2002. The Incas Have Gone inside: Pattern and Persistence in Andean Iconography. RES: Anthropology and Aesthetics 42 (autumn): 180-203. Cambridge: Peabody Museum.

Ampuero, G., 1978. Cultura Diaguita. Serie El Patrimonio Cultural Chileno, colección Culturas Aborígenes. Santiago: Departamento de Extensión Cultural del Ministerio de Educación.

Ampuero, G., 1989. La cultura Diaguita chilena (1200 a 1470 DC). En Prebistoria. Desde sus orígenes hasta los albores de la conquista. Culturas de Chile, J. Hidalgo, V. Schiappacasse, H. Niemeyer, C. Aldunate \& I. Solimano, Eds., pp. 277-288. Santiago: Editorial Andrés Bello.

Arenas, M. A., 2011. Representaciones rupestres en los Andes coloniales. Una mirada desde el sitio Toro Muerto (Comuna de La Higuera, IV Región de Coquimbo-Chile). Tesis para optar al título de Antropólogo, Universidad Academia de Humanismo Cristiano.

Armstrong, F., 2012. Engraved memory: Petroglyphs and collective memory at Los Mellizos, Illapel, Chile. Rock Art Research 29 (1): 19-34, Melbourne.

Aschero, C.; A. Martel \& S. López Campeny, 2009. El sonido del agua... Arte rupestre y actividades productivas. El caso de 
Antofagasta de la Sierra, Noroeste Argentino. En Crónicas sobre la piedra. Arte rupestre de las Américas, M. Sepúlveda, L. Briones \& J. Chacama, Eds., pp. 257-270. Arica: Ediciones Universidad de Tarapacá.

Ávalos, H. \& A. Saunier, 2011. Antecedentes arqueológicos en la cuenca del Aconcagua, 1996-2011. Capítulo 2. En Arqueología e historia del curso medio e inferior del río Aconcagua, F. Venegas, Ed., pp. 43-111. Valparaíso: Ediciones Universitarias de Valparaíso

Ávalos, H.; J. Strange, E. Valenzuela, A. Román \& M. Henríquez, 19992000. Evidencias Aconcagua en el curso inferior del río La Ligua. Valles. Revista de Estudios Regionales 5/6: 119-134, La Ligua.

BAHAMONDES, F., 2009. La cerámica prehispánica tardía de Araucanía Septentrional: El complejo arqueológico El Vergel y su relación con la hipótesis del proceso de Andinización. Memoria de Título, Departamento de Antropología, Universidad de Chile.

BAHAMONDES, F., 2010. Las sociedades prehispánicas tardías y coloniales de La Araucanía: La cerámica bícroma como elemento de continuidad socio-cultural (siglos X-XviII). En Actas del VI Congreso Chileno de Antropología, tomo II, pp. 1919-1931, Valdivia.

Ballereau, D., \& H. Niemeyer, 1999. Los sitios rupestres del valle del río Hurtado Superior (Norte Chico, Chile). Chungara 31 (2): 229-292.

BerdichewsKy, B., 1964. Informe preliminar de las excavaciones en Concon. Antropología, Revista del Centro de estudios Antropológicos, Año II, Vol. II. Nº 1: 65-86. Santiago: Universidad de Chile.

Berenguer, J., 2009a. Caravaneros y guerreros en el arte rupestre de Santa Bárbara, Alto Loa. En Crónicas sobre la piedra. Arte rupestre de las Américas, M. Sepúlveda, L. Briones \& J. Chacama, Eds., pp. 193-203. Arica: Ediciones Universidad de Tarapacá.

Berenguer, J., 2009b. Chile bajo el Imperio de los Inkas. Santiago: Museo Chileno de Arte Precolombino.

Berenguer, J., 2012 Ms. Unkus ajedrezados en el arte rupestre del sur del Tawantinsuyu: ¿La estrecha camiseta de la servidumbre? En Las tierras altas del Área Centro Sur Andina entre el 1000 y el 1600 DC. TANOA II, Taller Internacional de Arqueología del Noroeste Argentino y Andes Centro-Sur, M. E. Albeck, M. Ruiz \& B. Cremonte, Eds. Jujuy: EdiUNJu.

Bertonio, L., 1984 [1612]. Vocabulario de la lengua aymara. Cochabamba: CERES-IFEA.

BiBAR, G., 1966 [1558]. Crónica y relación copiosa y verdadera de los reynos de Chile. Santiago de Chile: Fondo Histórico J. T. Medina.

BOLLAERT, W., 1860. Antiquarian, ethnological and other researches in New Granada, Equador, Peru and Chile, with observations of the pre-incarial, incarial and other monuments of Peruvian nations. London: Trübner and Company.

BRAY, T., 2004. La alfarería imperial Inka: Una comparación entre la cerámica estatal del área de Cuzco y la cerámica de las provincias. Chungara 36 (2): 365-374.

CABELlO, G., 2005. Rostros que hablan: Una propuesta estilística para el arte rupestre de Chalinga, IV Región, Chile. Memoria para optar al título de Arqueóloga, Departamento de Antropología, Universidad de Chile.

Cantarutti, G., 2002. Estadio Fiscal de Ovalle: Redescubrimiento de un sitio Diaguita-Inca en el Valle de Limarí. IV Región de Coquimbo, Chile. Memoria para optar al título de Arqueólogo, Departamento de Antropología, Universidad de Chile.

CONNERTON, P., 1989. How societies remember. Cambridge: University Press.

Correa, I., 2009. Los complejos alfareros Llolleo y Pitrén. Un estudio comparativo a partir de piezas cerámicas completas. Memoria para optar al título de Arqueóloga, Departamento de Antropología, Universidad de Chile.

Cummins, T., 1998. Let me see! Reading is for them: Colonial Andean Images and Objects "como es costumbre tener los caciques Señores". En Native Traditions in the Postconquest World, E. Hill \& T. Cummins, Eds., pp. 91-147. Washington, D. C.: Dumbarton Oaks Research Library and Collection.
Dillehay, T., 2007. Monuments, Empires and Resistance. The Araucanian polity and ritual narratives. New York: Cambridge University Press.

DillehaY, T. \& A. Gordon, 1995. La actividad prehispánica de los incas y su influencia en la Araucanía. En La frontera del Estado Inca, T. Dillehay \& P. Netherly, Comps., pp. 183-197. Quito: Editorial Abya-Yala.

DORTA, E., 1975. Las pinturas que envió y trajo a España don Francisco de Toledo. Historia y Cultura 9: 67-78. Lima: Museo Nacional de Historia.

Durán, E., 1979. El yacimiento de María Pinto, sus correlaciones y ubicación cultural. En Actas del VII Congreso de Arqueología de Chile, pp. 261-276. Santiago: Museo Nacional de Historia Natural.

Durán, E. \& M. Massone, 1979. Hacia una definición del complejo cultural Aconcagua y sus tipos cerámicos. En Actas del VII Congreso de Arqueología de Chile, pp. 243-245. Santiago: Museo Nacional de Historia Natural.

DurÁn, E. \& M. Planella, 1989. Consolidación Agroalfarera: Zona central. En Prebistoria. Desde sus orígenes hasta los albores de la conquista. Culturas de Chile, J. Hidalgo, V. Schiappacasse, H. Niemeyer, C. Aldunate \& I. Solimano, Eds., pp. 313-328. Santiago: Editorial Andrés Bello.

Duviols, P., 1997. La interpretación del dibujo de Pachacuti Yamqui. En Saberes y memorias en los Andes. In memoriam Thierry Saignes, T. Bouysse-Cassagne, Ed., pp.101-114. Lima: IFEA.

Estenssoro, J. C., 2005. Construyendo la memoria: La figura del inca y el reino del Perú, de la conquista a Túpac Amaru II. En Los incas, reyes del Perú, pp. 93-173. Lima: Banco de Crédito del Perú.

Falabella, F. \& R. Stehberg, 1989. Los inicios del desarrollo agrícola y alfarero: Zona central (300 AC a 900 DC). En Prehistoria. Desde sus orígenes hasta los albores de la conquista. Culturas de Chile, J. Hidalgo, V. Schiappacasse, H. Niemeyer, C. Aldunate \& I. Solimano, Eds., pp. 295-311. Santiago: Editorial Andrés Bello.

Frezier, A., 1902 [1716]. Relación del viaje por el mar del sur a las costas de Chile i el Perú durante los años de 1712,1713 $i 1714$. Santiago: Imprenta Mejía.

Gallardo, F.; V. Castro \& P. Miranda, 1990. Jinetes sagrados en el desierto de Atacama: Un estudio de arte rupestre andino. Boletín del Museo Chileno de Arte Precolombino 4: 27-56.

Gallardo, F.; C. Sinclaire \& C. Silva, 1999. Arte rupestre, emplazamiento y paisaje en la cordillera del desierto de Atacama. En Arte Rupestre en los Andes de Capricornio, J. Berenguer \& F. Gallardo, Eds., pp. 57-96. Santiago: Museo Chileno de Arte Precolombino.

García, A., 1997. Alcances del dominio incaico en el extremo suroriental del Tawantinsuyu. Chungara 29 (2): 195-208.

GonZÁlez, P., 2004. Arte visual, espacio y poder: Manejo incaico de la iconografía cerámica en distintos asentamientos de la fase Diaguita Inka en el valle de Illapel. Chungara 36 (2): 375-392.

GONZález, P., 2013. Arte y cultura diaguita chilena. Simetría, simbolismo e identidad. Serie monográfica de la Sociedad Chilena de Arqueología, No 2. Santiago: Ucayali Editores.

González De NájerA, A., 1971 [1614]. Desengaño y reparo de la guerra del reino de Chile. Santiago: Editorial Andrés Bello.

HiDES, S., 1996. The genealogy of material culture and culture identity. En Cultural Identity and Archaeology. The Construction of European Communities, P. Graves-Brown, C. Jones \& C. S. Gamble, Eds., pp. 25-47. London: Routledge.

Horta, H., 2008. Insignias para la frente de los nobles incas: Una aproximación etnohistórica-arqueológica al principio de la dualidad. En Lenguajes visuales de los incas, BAR International Series 1848, P. González \& T. Bray, Eds., pp. 71-89. Oxford: Archaeopress.

Hostnig, R., 2004. Arte rupestre postcolombino de la Provincia de Espinar, Cusco, Perú. Boletín SIARB 18: 40-64, La Paz.

IribarRen, J., 1969. Hachas de piedra de formas extrañas en la provincia de Coquimbo. Boletín del Museo Arqueológico de La Serena 13: 41-44, La Serena.

Iribarren, J. \& H. Bergholz, 1972-1973. El camino del inca en un sector del norte chico. En Actas del vi Congreso de Arqueología 
Chilena, Boletín de Prehistoria, Número especial, pp. 229-266. Santiago: Universidad de Chile.

ITIER, C., 1997. Las fuentes quechuas coloniales y la etnohistoria: El ejemplo de la relación de Pachacuti. En Saberes y memorias en los Andes. In memoriam Thierry Saignes, T. Bouysse-Cassagne, Ed., pp.93-100. Lima: IFEA.

Jackson, D.; D. Artigas \& G. Cabello, 2002. Trazos del Choapa. Arte rupestre en la cuenca del rí Choapa. Una perspectiva macroespacial. Santiago: Universidad de Chile.

JafFuel, F., 1930. Las piedras pintadas del cajón de los cipreses (Hoya del Cachapoal). Revista Chilena de Historia Natural 34 (1): 235-248, Santiago.

Lagos, G., 1985. Los títulos históricos. Historia de las fronteras de Chile. Santiago: Editorial Andrés Bello.

LARREA, J., 1941. El Yauri, insignia incaica. Revista del Museo Nacional $\mathrm{X}(1)$ : 25-50, Lima.

LATORRE, E., 2009. De adornos y herramientas nacidos del fuego: Una caracterización del trabajo de metales en la Cultura Diaguita (ca. 900-1536 DC). Memoria para optar al título de Arqueólogo. Universidad de Chile.

LAtorre, E. \& P. López, 2011. Los metales en la cultura Diaguita chilena (ca. 900-1536 DC): Una aproximación metodológica e interpretativa. Intersecciones en Antropología 12: 319-332.

LEÓN, L., 1983. Expansión inca y resistencia indígena en Chile, 1470-1536. Chungara 10: 95-115.

Llagostera, A., 1976. Hipótesis sobre la expansión incaica en la vertiente occidental de los Andes meridionales. Anales de la Universidad del Norte (Chile) 10: 203-218, Antofagasta.

Llagostera, A.; R. Weisner, G. Castillo, M. Cervellino \& M. A. CosTA, 2000. El complejo Huentelauquén bajo una perpectiva macroespacial y multidisciplinaria. En Actas del XIV Congreso Nacional de Arqueología Chilena. Contribución Arqueológica 5, pp. 461-481.

Madrid, J., 1969. Petroglifos del Cerro Los Ratones. Cajón del Maipo, Prov. de Santiago. En Actas del v Congreso Nacional de Arqueología, pp. 277-294. La Serena: DIBAM.

MADRID, J., 1977. Ocupación indígena en el valle superior del río Maipo. Tesis para optar al grado de Licenciado en Arqueología y Prehistoria, Universidad de Chile.

Martel, Á.; S. Rodríguez \& E. Del Bel, 2012. Arte rupestre y espacios de memoria: Las representaciones del sitio Confluencia (Antofagasta de la Sierra, Catamarca, Argentina). Revista Chilena de Antropología 25: 121-162, Santiago.

Martínez, J. L., 1998. Pueblos del Chañary El Algarrobo. Los Atacamas en el siglo XVII. Santiago: DIBAM.

MarTíneZ, J. L., 2009. Registros andinos al margen de la escritura: $\mathrm{El}$ arte rupestre colonial. Boletín del Museo Chileno de Arte Precolombino 14 (1): 9-35.

Martínez, J. L., 2010. "Mandó pintar dos aves...": Relatos orales y representaciones visuales andinas. Chungara 42 (1): 157-167.

MartíneZ, J. L. \& M. Arenas, 2009. Problematizaciones en torno al arte rupestre colonial en las áreas centro sur y meridional andina. En Crónicas sobre la piedra. Arte rupestre de las Américas, M. Sepúlveda, L. Briones \& J. Chacama, Eds., pp. 129-140. Arica: Universidad de Tarapacá.

Martínez, P., 2011. Algunas reflexiones sobre las prácticas escriturarias en los Andes coloniales. Atenea 503: 93-109, Concepción.

Mignolo, W., 1992. On the Colonization of Amerindian Languages and Memories: Renaissance Theories of Writing and the Discontinuity of the Classical Tradition. Comparative Studies in Society and History 34 (2): 301-335. Cambridge: CSSH.

Miranda, P. \& M. SAAVEDRa, 1997. Arte rupestre en el río Colorado, Cajón del Maipo. Boletín Sociedad Chilena de Arqueología 24: 18-19, Santiago.

Montt, I. \& G. Pimentel, 2009. Grabados antropomorfos tardíos. El caso de las personificaciones de hachas en San Pedro de Atacama (Norte de Chile). En Crónicas sobre la piedra. Arte rupestre de las Américas, M. Sepúlveda, L. Briones \& J. Chacama, Eds., pp. 221-233. Arica: Universidad de Tarapacá.
Mostny, G. \& H. Niemeyer, 1983. Arte rupestre chileno. Santiago: Ministerio de Educación.

Museo Chileno de Arte Precolombino, 1991. Diaguitas. Pueblos del Norte verde. Segunda edición. Santiago: Museo Chileno de Arte Precolombino.

Nielsen, A., 2007. Armas significantes: Tramas culturales, guerra y cambio social en el sur andino prehispánico. Boletín del Museo Chileno de Arte Precolombino 12 (1): 9-41.

Niemeyer, H., 1958. Ocupación indígena en el río Colorado, afluente del Maipo. Revista Universitaria 22: 117-122. Santiago: Universidad Católica de Chile.

Niemeyer, H. \& L. WeISNer, 1972-1973. Los petroglifos de la cordillera andina de Linares. En Actas del vi Congreso de Arqueología Chilena, Boletín de Prehistoria, Número especial, pp. 405-470. Santiago: Universidad de Chile.

Niemeyer, H. \& V. León, 2001. Arte rupestre precolombino en el Tinguiririca. Provincia de Colchagua. Sexta Región de Chile. Santiago: Gráfica Escorpio.

Pavlovic, D.; R. SÁnchez \& A. Troncoso, 2003. Prehistoria de Aconcagua. San Felipe: Ediciones del Centro Almendral.

PeAse, F., 1997. Los cronistas y la escritura de la historia incaica. En Arqueología, antropología e bistoria en los Andes. Homenaje a María Rostworoski, R. Varón \& J. Flores, Eds., pp. 115-126. Lima: IEP-BCRP.

Planella, M. T. \& R. Stehberg, 1994. Etnohistoria y arqueología de la fortaleza indígena de Cerro Grande de La Compañía. Chungara 26 (1): 65-78.

Rowlands, M., 1993. The role of memory in the transmission of culture. World Archaeology 25 (2): 141-151, London.

Ryn, Z., 2000. Historia científica de Los Andes. Don Ignacio Domeyko (1802-1889). Revista del CESLA 1: 151-169, Varsovia.

Salomon, F., 1994. La textualización de la memoria en la América andina: Una perspectiva etnográfica comparada. América Indigena 54 (4): 229-261, México, D. F.

SÁnchez, R., 2004. El Tawantinsuyu en Aconcagua (Chile central). Chungara 36 (2): 325-336.

SÁnchez, R. \& A. Troncoso, 2008. Arquitectura, arte rupestre y las nociones de exclusión e inclusión: El Tawantinsuyu en Aconcagua, Chile central. En Lenguajes visuales de los incas, BAR International Series 1848, P. González \& T. Bray, Eds., pp. 125-131. Oxford: Archaeopress.

Sánchez, R.; D. Pavlovic, P. González \& A. Troncoso, 2004. Curso superior del río Aconcagua. Un área de interdigitación cultural períodos Intermedio Tardío y Tardío. Chungara, Vol. Esp. Tomo II: 735-766.

Sanhueza, L. \& F. Falabella, 2009. Descomponiendo el complejo Llolleo: Hacia una propuesta de sus niveles mínimos de integración. Chungara 41 (2): 229-239.

Sepúlveda, J.; A. San Francisco, B. Jiménez \& S. Pérez, 2014. El pucará del cerro La Muralla. Santiago: Mutante Editores.

STEHBERG, R., 1977. Reflexiones acerca de la fortaleza inca de Chena. Revista de Educación 62: 46-51, Santiago.

STEHBERG, R., 1995. Instalaciones incaicas en el norte y centro semiárido de Chile. Santiago: DIBAM.

STEHBERG, R. \& A. Rodríguez, 1989. Ofrendatorio mapuche-incaico en el cerro Tren-Tren de Doñihue. Revista Museos 6: 8-11, Santiago.

TAYLOR, G., 2008. Ritos y tradiciones de Huarochirí. Edición bilingüe quechua normalizado - castellano. Lima: IFEA.

Troncoso, A., 2001. Sobre el arte rupestre en el valle de Aconcagua y de por qué los signos escudos son incaicos. En Actas del $4^{\circ}$ Congreso Chileno de Antropología, pp. 192-198, Santiago: LOM Editores.

Troncoso, A., 2004. El arte de la dominación: Arte rupestre y paisaje durante el período incaico en la cuenca superior del río Aconcagua. Chungara 36 (2): 453-461.

Troncoso, A., 2005. Genealogía de un entorno rupestre en Chile central: Un espacio, tres paisajes, tres sentidos. Boletín del Museo Chileno de Arte Precolombino 10 (1): 35-53. 
Troncoso, A., 2006a. Arte rupestre en la cuenca del río Aconcagua: Formas, sintaxis, estilo, espacio y poder. Tesis doctoral, Universidad de Santiago de Compostela.

Troncoso, A., 2006b. Nuevos antecedentes para la definición de estilos en el arte rupestre de la cuenca superior del río Aconcagua. Revista Werkén 8: 41-56. Santiago: Universidad Internacional SEK.

Troncoso, A., 2011. Personajes fuera de lugar: Antropomorfos tardíos en el arte rupestre del norte semiárido de Chile. Intersecciones en Antropología 12: 221-230.

Troncoso, A.; F. Armstrong, F. Vergara, P. Urzúa \& P. Larach, 2008. Arte rupestre en el valle El Encanto (Ovalle, Región de
Coquimbo): Hacia una revaluación del sitio-tipo del Estilo Limarí. Boletín del Museo Chileno de Arte Precolombino 13 (2): 9-36.

Valenzuela, A., 1964. Toqui mano. En Arqueología de Chile Centraly áreas vecinas, Actas del III Congreso Internacional de Arqueología Chilena, pp. 157-169, Santiago: Imprenta Los Andes.

Vega, T.; M. Martínez, M. Piombo, P. Bestard, M. Gelós \& C. Seró, 1996. Profundización de los aspectos estéticos de petroglifos y pictografías de la provincia el Neuquén. I Parte. Chungara 28 (1-2): 365-379.

Vergara, C., 1972-1973. Petroglifos de las piedras de Las Marcas. En Actas del VI Congreso de Arqueología Chilena, Boletín de Prehistoria, Número especial, pp. 471-485. Santiago: Universidad de Chile. 